\title{
DISCRETE SUSPENDED PARTICLES OF BARITE AND THE BARIUM CYCLE IN THE OPEN OCEAN
}

\author{
F. DEHAIRS ${ }^{1, *}$, R. CHESSELET $^{2}$ and J. JEDWAB ${ }^{1}$ \\ ${ }^{1}$ Laboratoire de Géochimie, Université Libre de Bruxelles, 50, Avenue Roosevelt, B-1050 Brussels (Belgium) \\ ${ }^{2}$ Centre des Faibles Radioactivités, Laboratoire mixte CEA-CNRS, 91190 Gif-sur-Yvette (France)
}

Received January 5, 1979

Revised version received May 29, 1979

\begin{abstract}
Barite particles are a universal component of suspended matter in the Atlantic and Pacific Oceans. This is demonstrated by scanning electron microscope and electron microprobe analyses of samples collected during the GEOSECS program. These discrete particles, about $1 \mu \mathrm{m}$ in diameter, account for by far the greatest part of the total particulate barium of most of the filters collected at different depths. Total particulate barium (mean value: 20 $\mathrm{ng} / \mathrm{kg}$ seawater) was measured on the same filters by instrumental neutron activation analysis.

Several observations indicate that biochemical, rather than purely chemical, processes are involved in the formation of the $\mathrm{BaSO}_{4}$ mineral in the water column. Sr/Ba molar ratios among the individual barite grains, particularly from surface waters are extremely variable, which would not be anticipated for purely chemical interactions. Barite crystals occurring within fecal debris have been observed throughout the water column. Within such debris decomposition of the abundant organic matter may provide the micro-environment predicted as necessary for the precipitation of $\mathrm{BaSO}_{4}$. Finally, a strong correlation between nutrient content and particulate barium is found in the upper $1000 \mathrm{~m}$ of the water column, which also suggests a control of barite formation by biota.

Some of the barite dissolves at depth in the water column. Dissolution rates were calculable for two GEOSECS stations, from which a dissolved barium flux of $0.4 \mu \mathrm{g} / \mathrm{cm}^{2} \mathrm{yr}$ was deduced. This figure is of the same order as the dissolved barium flux calculable from the barium content and known dissolution rates of calcareous and siliceous tests: approximately $0.5 \mu \mathrm{g} / \mathrm{cm}^{2}$ yr. These fluxes represent the largest source of dissolved barium in the water column, the other being river input $\left(0.6 \mu \mathrm{g} / \mathrm{cm}^{2} \mathrm{yr}\right)$. This supports the contention that the barium in the water column is mostly recycled. The residual flux of barite-Ba reaching the sea floor is of about equal importance as the flux of barium associated with fast-settling fecal material. These two sources together are almost sufficient to account for the total sedimentation rate of barium.
\end{abstract}

\section{Introduction}

During the past twenty years the distribution of dissolved $\mathrm{Ba}$ in the world ocean has been extensively studied $[1,2]$. The profiles of dissolved $\mathrm{Ba}$ are characterized by a depletion in surface water and an enrichment in deep water. This suggests a close association of $\mathrm{Ba}$ with the biological cycle $[3,4]$.

An association of $\mathrm{Ba}$ with biogenic particles is

\footnotetext{
* Present address: Dienst Analy tische Scheikunde, Vrije Universiteit Brussel, 2 Pleinlaan, B-1050 Brussels, Belgium.
}

GEOSECS Publication No. 125. deduced from the fact that sediments underlying highly productive surface waters are enriched in $\mathrm{Ba}$ [5-8] and subsequently in sedimentary barite [7]. Submarine volcanism however, may be locally important [9]. Because of the good correlation observed between dissolved barium and silicon in the water column it has been suggested that the distribution of both elements is governed by the dissolution of $\mathrm{Ba}$ enriched siliceous frustules $[4,10-12]$. This conclusion was supported by earlier observations that some diatom species are able to accumulate significant amounts of $\mathrm{Ba}[13,14]$.

Other ideas have been put forward concerning the mechanism of $\mathrm{Ba}$ uptake by organisms and by their 
detritus. A precipitation of barium sulphate in decaying, sulphate-rich organic micro-environments was proposed by Chow and Goldberg [1]. Likewise, Turekian [15] concluded that the distribution of $\mathrm{Ba}$ in the sediments could be explained by the production of barium sulphate crystals in association with biological activity and their partial dissolution in deep water. The involvement of barite in at least some biological processes has been confirmed by the observation of barite crystals within the protoplasm of abyssal benthic Rhizopoda of the class Xenophyophorida $[16,17,45]$.

Previous to the first measurements of particulate barium in suspended matter samples [18] (collected during the 1972 R.V. "Jean Charcot" cruise (Harma$\tan$ expedition) in the Equatorial Atlantic and the Gulf of Guinea), no direct evidence of the presence of a barium-rich phase in suspension was available.

The data presented here were mostly obtained during the GEOSECS program $[19,20]$. Scanning electron microscope and electron microprobe (SEM-EMP) analyses have permitted the identification of a barium- and sulphur-rich phase in samples of suspended matter in seawater. The chemical composition and electron micro-diffractometry observations confirm the identification of these particles as barite. The mass of Ba carried by the barite particles was estimated from particle size measurements by electron microscopy and was subsequently compared with data on total particulate $\mathrm{Ba}$, obtained for the same samples by instrumental neutron activation analysis (INAA). In this study we attempt to elucidate the origin of suspended barite and its importance as a source of dissolved $\mathrm{Ba}$ in deep water and of sedi-

TABLE 1

Geographical position of stations and investigated depth intervals

\begin{tabular}{|c|c|c|}
\hline Stations & Positions & Investigated depth (interval in meters) \\
\hline \multicolumn{3}{|l|}{ Atlantic Ocean } \\
\hline GEOSECS station 17 & $74^{\circ} 56^{\prime} \mathrm{N}, 01^{\circ} 07^{\prime} \mathrm{W}$ & $992-3439 a$ \\
\hline 5 & $56^{\circ} 54^{\prime} \mathrm{N}, 42^{\circ} 47^{\prime} \mathrm{W}$ & $363-2464$ a \\
\hline 3 & $51^{\circ} 01^{\prime} \mathrm{N}, 43^{\circ} 01^{\prime} \mathrm{W}$ & $28-3660 \mathrm{a}, \mathrm{b}$ \\
\hline 27 & $42^{\circ} 00^{\prime} \mathrm{N}, 41^{\circ} 59^{\prime} \mathrm{W}$ & $1441-4858$ a \\
\hline 31 & $27^{\circ} 00^{\prime} \mathrm{N}, 53^{\circ} 31^{\prime} \mathrm{W}$ & $1-5500^{b}$ \\
\hline 58 & $27^{\circ} 02^{\prime} \mathrm{S}, 37^{\circ} 00^{\prime} \mathrm{W}$ & $197-4422 \mathrm{a}, \mathrm{b}$ \\
\hline 67 & $44^{\circ} 58^{\prime} \mathrm{S}, 50^{\circ} 10^{\prime} \mathrm{W}$ & $40-5580$ a,b \\
\hline 91 & $49^{\circ} 36^{\prime} \mathrm{S}, 11^{\circ} 37^{\prime} \mathrm{E}$ & $486-3074$ a \\
\hline 82 & $56^{\circ} 15^{\prime} \mathrm{S}, 57^{\circ} 38^{\prime} \mathrm{W}$ & $1-5202 \mathrm{a}, \mathrm{b}$ \\
\hline ATLANTIS II station 715 & $52^{\circ} 56^{\prime} \mathrm{N}, 36^{\circ} 13^{\prime} \mathrm{W}$ & $2000^{a}$ \\
\hline 2111 & $33^{\circ} 41^{\prime} \mathrm{N}, 57^{\circ} 38^{\prime} \mathrm{W}$ & $2195^{a}$ \\
\hline HARMATAN 1971 station 6 & $04^{\circ} 30^{\prime} \mathrm{N}, 19^{\circ} 35^{\prime} \mathrm{W}$ & $2000-3000 a$ \\
\hline 15 & $00^{\circ} 00^{\prime}, 05^{\circ} 30^{\prime} \mathrm{W}$ & $1000-4000$ a \\
\hline MIDLANTE 1974 station 50 & $34^{\circ} 43^{\prime} \mathrm{N}, 29^{\circ} 34^{\prime} \mathrm{W}$ & $985-3510 b$ \\
\hline Madcap & $28^{\circ} 40^{\prime} \mathrm{N}, 25^{\circ} 25^{\prime} \mathrm{W}$ & $1075-5043 \mathrm{~b}$ \\
\hline TRANSAT 1975 station 17 & $34^{\circ} 06^{\prime} \mathrm{N}, 61^{\circ} 17^{\prime} \mathrm{W}$ & $5-4380 b$ \\
\hline \multicolumn{3}{|l|}{ Pacific Ocean } \\
\hline GEOSECS station 257 & $10^{\circ} 10^{\prime} \mathrm{S}, 170^{\circ} 00^{\prime} \mathrm{W}$ & $1263-5182 a, b$ \\
\hline 263 & $16^{\circ} 36^{\prime} \mathrm{S}, 167^{\circ} 05^{\prime} \mathrm{W}$ & $676^{a}$ \\
\hline 269 & $23^{\circ} 59^{\prime} \mathrm{S}, 174^{\circ} 26^{\prime} \mathrm{W}$ & $1253-6348^{a, b}$ \\
\hline 310 & $26^{\circ} 55^{\prime} \mathrm{S}, 157^{\circ} 11^{\prime} \mathrm{W}$ & $1557-4789 a, b$ \\
\hline 282 & $57^{\circ} 35^{\prime} \mathrm{S}, 169^{\circ} 36^{\prime} \mathrm{E}$ & $2131-5187 \mathbf{a , b}$ \\
\hline
\end{tabular}

a Inspected for $\mathrm{BaSO}_{4}$ presence by SEM-EMP.

b Analysed for total $\mathrm{Ba}_{\mathrm{p}}$ by INAA. 
mentary barite. The geographic coverage of this study can be ascertained by examining the locations of the suspended matter profiles in Table 1.

\section{Methods}

Specific details concerning the techniques of sampling, filtration and weighing of total suspended matter during the GEOSECS program are given in Brewer et al. [21].

\subsection{Chemical analysis of particulate barium by instrumental neutron activation analysis}

Quantitative analysis of particulate $\mathrm{Ba}\left(\mathrm{Ba}_{\mathrm{p}}\right)$ was performed by INAA, at the Centre des Faibles Radioactivités (CFR, CNRS-CEA *, Gif-sur-Yvette, France) using the facilities of the Pierre Süe Activation Analysis Laboratory (CNRS-CEA, Saclay, France).

The samples were pelletized using a specially designed stainless steel press. The standards consisted of multi-element solutions, including Ba, adsorbed on pelletized Whatman No. 41 filters. These standards, as well as blanks, were included on each irradiation run of suspended matter samples. After an irradiation of $10 \mathrm{~min}$. in a neutron flux of the order of $2.3 \times 10^{13}$ neutrons $/ \mathrm{cm}^{2} \mathrm{~s}$ in the EL3 reactor at Saclay Nuclear Centre, we analysed for ${ }^{139} \mathrm{Ba}$ (period: 89 minutes; ${ }^{138} \mathrm{Ba}(\mathrm{n}, \gamma)$ ), with a Ge-Li detector having a resolution of about $1 \mathrm{keV} /$ channel.

The $2 \sigma$ confidence levels mentioned in the tables and figures are determined by the counting statistics in the $166-\mathrm{keV}$ photo-peak region.

\subsection{Electron microscope and electron microprobe analysis}

\section{Determination of the elemental composition of} barium-rich particles by SEM-EMP. The elemental composition and morphology of Ba-rich particles were studied at the Université Libre de Bruxelles (for some samples at CFR), using scanning electron micro-

\footnotetext{
* Centre des Faibles Radioactivités, Centre National de la Recherche Scientifique-Commissariat à l'Energie Atomique,
}

scopes equipped with electron microprobes. Both energy-dispersive spectrometers (EDS) with software facilities for X-ray data treatment, and wavelengthdispersive spectrometers (WDS) were used.

For SEM-EMP investigation, the sample consisted of a small portion (approximately $0.5 \mathrm{~cm}^{2}$ ) of the original filter, mounted with colloidal carbon onto an aluminium stub and vacuum coated with carbon.

The EMP detection of Ba-rich particles was accomplished by one or the other of the following methods:

(1) By scanning the sample at constant magnification; every particle composed of high- $Z$ elements $(Z>13)$, was checked for dominance by $\mathrm{Ba}$ and $\mathrm{S}$ with the EDS. As is well known, the EDS cannot resolve the Ti- $K$ and the Ba- $L$ lines. Definitive identification was based on the appearance of the general spectrum or by checking with the WDS, which resolves both lines.

(2) By a semi-automatic method which consisted of scanning several fields at a low magnification $(600 \times$ or $12,000 \times)$ with the WDS set to diffract the $\mathrm{Ba}-L_{\alpha}$ spectral line, while the Ba X-ray map was photographically recorded and compared with the SEM picture in order to localize the Ba containing particles. These were checked with the EDS for S content.

For both methods, if $\mathrm{Ba}$ and $\mathrm{S}$ were present as the only principal components $(\mathrm{K}, \mathrm{Sr}$ are sometimes present in minor amounts), the particle was recorded as barium sulphate.

The detection limit of the EDS system is between 100 and $1000 \mathrm{ppm}$.

Confirmation of the suspended barium sulphate particles as barite. Electron micro-diffraction patterns of Ba- and S-rich particles in the GEOSECS suspended matter samples were obtained by Klossa [22]. These particles are dense and highly absorbant and proved to be extremely opaque to electrons. In order to obtain a definitive identification the use of a $1-\mathrm{MeV}$ electron microscope, equipped with a goniometer stage, was required. We illustrate this work (Fig. 1) with an easily oriented single crystal, for which it was possible to identify a large number of crystal plane families, according to the degree of rotation and inclination of the stage. The results confirm that it is a highly crystalline barite particle. 

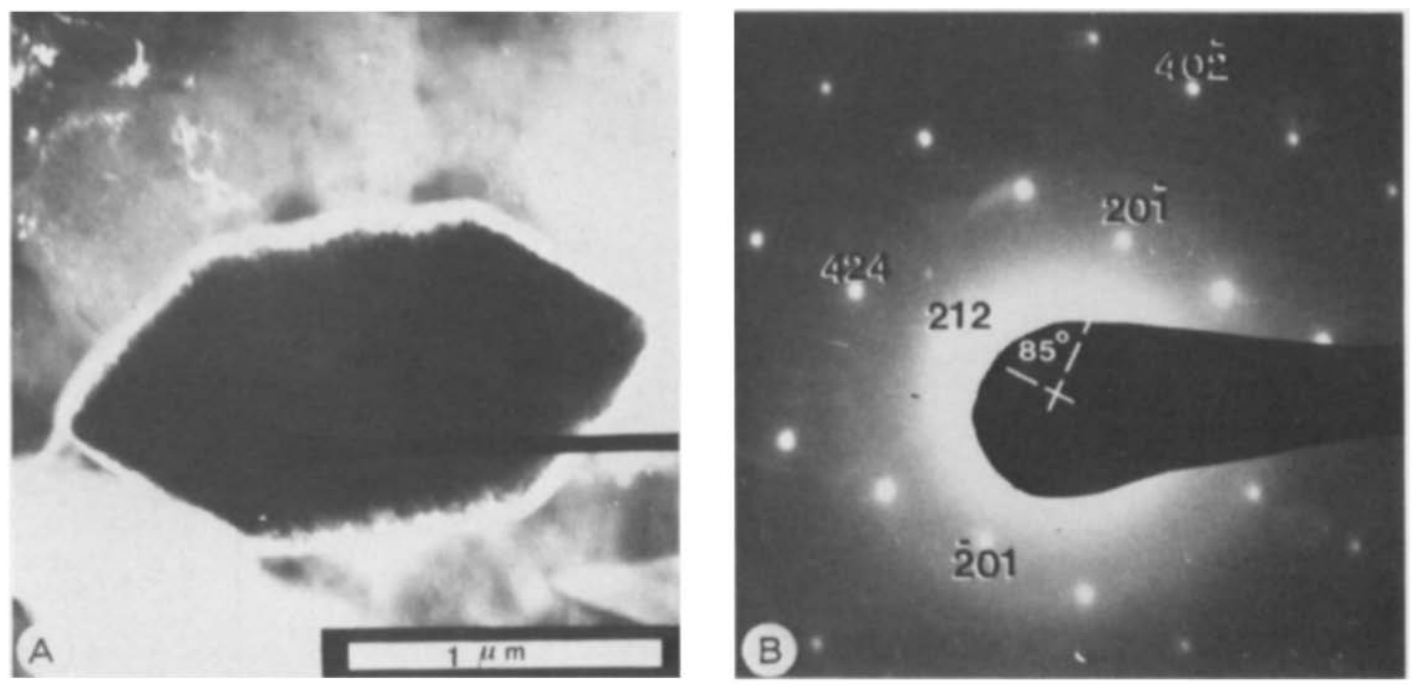

Fig. 1. Dark-field micrograph, obtained with a 1-MeV transmission electron microscope, of a single $\mathrm{BaSO}_{4}$ grain, previously located on the filter by SEM-EMP (1860 m, GEOSECS station 17). Despite the penetrating power of the 1-MeV electrons only grain margins permitted any intense diffraction (A). In B one can distinguish the planes of the (212) and the (201) families, which form an angle of $85^{\circ}$. (From J. Klossa, Laboratoire R. Bernas, Orsay and Centre des Faibles Radioactivités, Gif-sur-Yvette.)

Estimation of the mass of barium carried by barite particles. We evaluated the contribution of the barite particles to the total particulate $\mathrm{Ba}$ for 12 samples from GEOSECS station 67;8 samples from GEOSECS station 3 and 2 samples from GEOSECS station 5. To do this required that the mass of $\mathrm{Ba}$ carried by the barite grains be known. Particle size analysis was thus a prerequisite for the computation of particle masses. This was done by the following procedure. In order to more easily observe the sparsely scattered grains we reconcentrated the particles by resuspending the filtered matter present on 1/4 (225 $\mathrm{mm}^{2}$ ) of the original Nuclepore membranes in prefiltered A.R. grade $\mathrm{CCl}_{4}$, and re-filtered onto a much smaller Nuclepore membrane surface $\left(37 \mathrm{~mm}^{2}\right)$ under a laminary flow hood. The samples were then prepared for SEM-EMP analysis as discussed above. The barite particles detected were photographed at a fixed magnification $(12,000 X)$. The images were projected on a scan table equipped with a coordinatograph. The final magnification at the scan table was $30,000 \times$ and the accuracy of the size measurements was $0.003 \mu \mathrm{m}$.

Only two-dimensional images are obtainable but since most of the barite particles were equant and rounded we have used the convention of projected area diameters [23] to obtain estimates of grain volumes. After inserting the projected area diameters into classes of a geometric progression a histogram of size (volume) distribution was obtained. The mass of Ba of equivalent spheres was then calculated with the following equation:

$M=\frac{\pi}{6} \rho\left(\sum_{i} N_{i} D_{i}^{3}\right) F V$

with $M=$ Ba mass carried by barite particles $(\mathrm{g} / \mathrm{kg}$ seawater $) ; \rho=\mathrm{BaSO}_{4}$ density $\left(4.5 \mathrm{~g} / \mathrm{cm}^{3}\right) ; N_{i}=$ particle number in size class $i$ (number $/ \mathrm{kg}$ seawater); $D_{i}=$ projected area diameter; $=$ class-midpoint of class $i(\mathrm{~cm})$; $F=$ molar fraction of $\mathrm{Ba}$ in $\mathrm{BaSO}_{4}(0.59)$; and $V=$ ratio of the unit volume of seawater (1 liter) to the volume of filtered seawater which is equivalent to the scanned filter surface.

\section{Results}

\subsection{The concentration of particulate barium in sea- water as a function of depth (INAA data)}

The profiles of total particulate barium $\left(\mathrm{Ba}_{\mathrm{p}}\right)$ measured for the Atlantic and Pacific Ocean by INAA are 


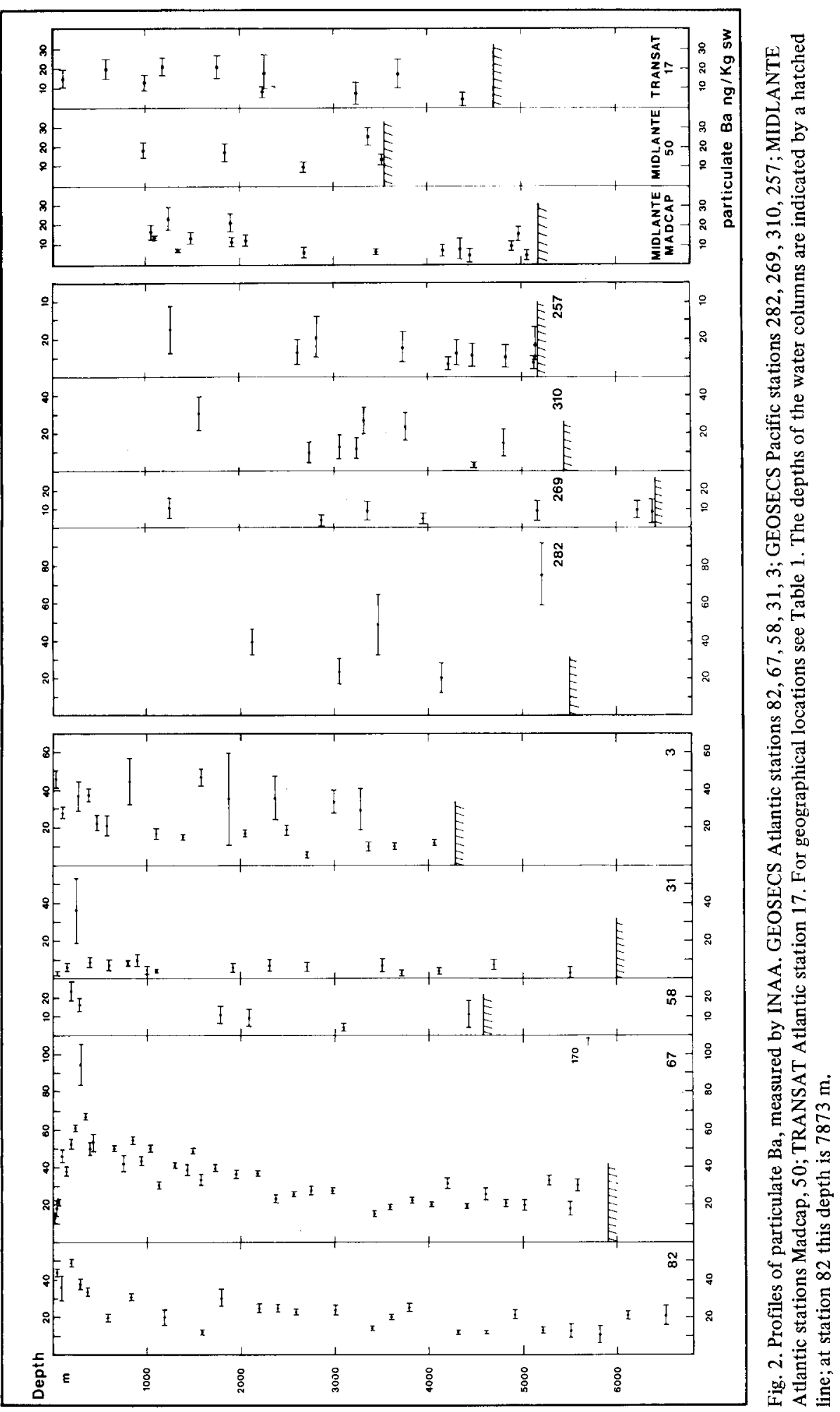


TABLE 2

Mean suspended barium concentration (geometric means) in surface water, in intermediate and deep water and in bottom water

\begin{tabular}{|c|c|c|c|c|c|c|}
\hline \multirow[t]{2}{*}{$\begin{array}{l}\text { Region in the } \\
\text { water column }\end{array}$} & \multicolumn{3}{|c|}{$\begin{array}{l}\text { Stations at high latitudes: } \\
\text { north of } 45^{\circ} \mathrm{N} \text { and south of } 45^{\circ} \mathrm{S}\end{array}$} & \multicolumn{3}{|c|}{ Stations between $45^{\circ} \mathrm{N}$ and $45^{\circ} \mathrm{S}$} \\
\hline & stations & $\begin{array}{l}\text { number of } \\
\text { investigated } \\
\text { samples }\end{array}$ & $\begin{array}{l}\mathrm{Ba} \text {. } \\
(\mathrm{ng} / \mathrm{kg} \mathrm{sw})\end{array}$ & stations & $\begin{array}{l}\text { number of } \\
\text { investigated } \\
\text { samples }\end{array}$ & $\begin{array}{l}\mathrm{Ba}_{\mathrm{p}} \\
(\mathrm{ng} / \mathrm{kg} \mathrm{sw})\end{array}$ \\
\hline Surface water & GEOSECS $82,67,3$ & 14 & 27 & GEOSECS 58,31 & 5 & 11 \\
\hline $\begin{array}{l}\text { Intermediate } \\
\text { and deep water }\end{array}$ & GEOSECS $82,67,3,282$ & 72 & 27 & $\begin{array}{l}\text { GEOSECS } 58,31 \text {, } \\
310,269,257 \\
\text { MIDLANTE } 50, \\
\text { Madcap } \\
\text { TRANSAT } 17\end{array}$ & 62 & 10 \\
\hline $\begin{array}{l}\text { Region in the } \\
\text { water column }\end{array}$ & Stations & $\begin{array}{l}\text { Number of } \\
\text { investigated } \\
\text { samples }\end{array}$ & \multicolumn{4}{|c|}{$\begin{array}{l}\mathrm{Ba}_{\mathrm{p}} \\
\text { (ng/kg seawater) }\end{array}$} \\
\hline Bottom water a & $\begin{array}{l}\text { GEOSECS } 82,67,58 \text {, } \\
31,3,310,269,257,282 \\
\text { MIDLANTE } 50 \text {, Madcap } \\
\text { TRANSAT } 17\end{array}$ & 28 & 14 & & & \\
\hline
\end{tabular}

a For the bottom waters no systematic variation of the $B a_{p}$ content with latitude is observed.

presented in Fig. 2. In order to emphasize geographic differences in the values the condensed data (geometric means) are reproduced in Table 2.

\subsection{Barite in suspended matter (SEM-EMP data)}

Geographical distributions. Our SEM-EMP analyses of samples collected at the stations listed in Table 1, which cover the North, Equatorial and South Atlantic, the Antarctic and the Central and South Pacific Oceans, reveal that $\mathrm{Ba}_{\mathrm{p}}$ is almost exclusively present as discrete barite particles of about $1 \mu \mathrm{m}$ diameter. These particles were observed in all investigated samples.

Elemental compositions. The suspended barite particles contain minor amounts of $\mathrm{Sr}$ and $\mathrm{K}$. In the surface waters a broad range of $\mathrm{Sr} / \mathrm{Ba}$ ratios exist. A semi-quantitative SEM-EMP study of $100 \mathrm{Ba}$-, Sr- and S-rich particles, collected in the surface water $(200 \mathrm{~m})$ at GEOSECS station 58, revealed that for $67 \%$ of the particles the strontium sulphate fraction, $N_{\mathrm{SrSO}_{4}}$ (with $N_{\mathrm{SrSO}_{4}}+N_{\mathrm{BaSO}_{4}}=1$ ), was $\leqslant 0.1$; for
$22 \% N_{\mathrm{SrSO}_{4}}$ was between 0.1 and 0.5 and for $11 \%$ $N_{\mathrm{SrSO}_{4}}$ was $>0.5$ (P. Buat-Menard and C. Jehanno, personal communication; see Figs. 3, 4 and 5C). Bafree, Sr- and S-rich particles are also present, either as biogenic debris (Acantharia debris; Fig. 5A, B), or as smaller particles with no obvious biogenic morphology (Fig. 5D).

Morphology. The most frequently observed morphologies for barite particles are, in decreasing order of frequencies (see Fig. 6):

- Ellipsoïdal or spherical particles.

- Particles with a distinct crystalline habit (euhedral, automorphic particles).

- Irregularly shaped particles that were probably affected by dissolution.

- Aggregates of very small particles (sub-micron sized) with or without a crystalline habit.

\subsection{Non-barite particles containing barium (SEM- EMP data)}

Particles with $\mathrm{Ba}$ as a minor constituent also occur. These particles measure between a few microns to 


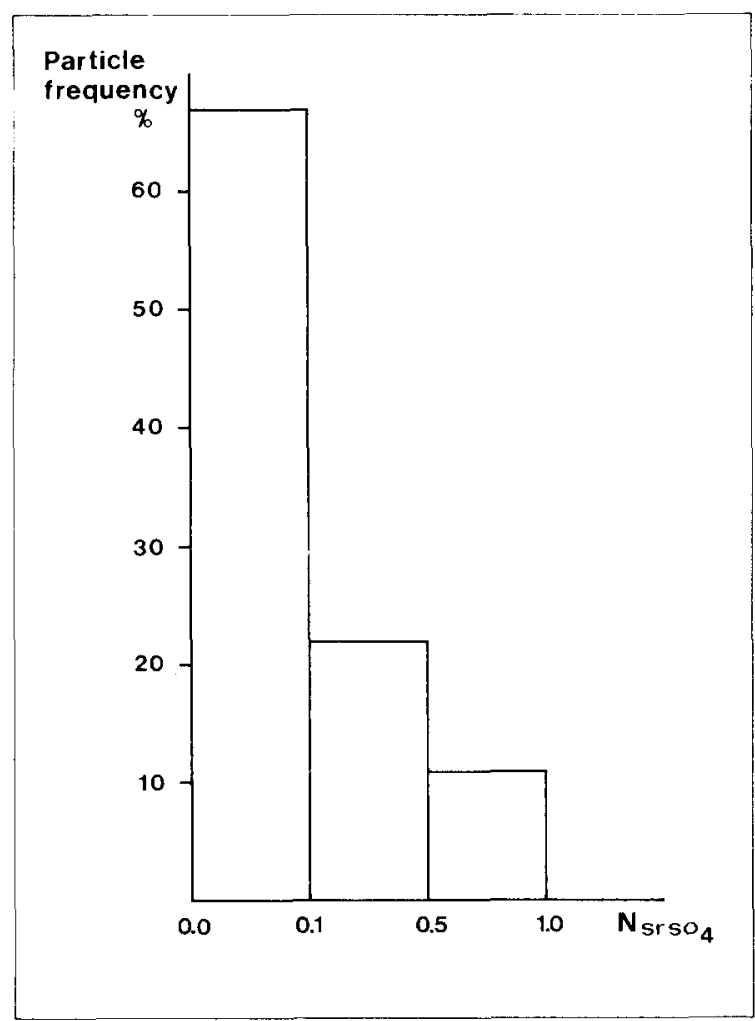

Fig. 3. Frequency histograms of $(\mathrm{Ba}, \mathrm{Sr}) \mathrm{SO}_{4}$ and $(\mathrm{Sr}, \mathrm{Ba}) \mathrm{SO}_{4}$ particles as a function of their $\mathrm{SrSO}_{4}$ fraction $\left(N_{\mathrm{SrSO}_{4}}\right)$, for the sample from $200 \mathrm{~m}$, GEOSECS station 58 . We take $N_{\mathrm{SrSO}_{4}}+N_{\mathrm{BaSO}_{4}}=1$. Data obtained by P. BuatMenard and C. Jehanno at the Centre des Faibles Radioactivités, Gif-sur-Yvette.

several tens of microns. Two categories of such Bacontaining particles are distinguishable, based upon the nature of their principal elements:

- Particles with $\mathrm{Fe}$ as the major constituent. Si, $\mathrm{Ca}, \mathrm{Al}$ and occasionally $\mathrm{S}, \mathrm{Cl}$ are detected. Discrete Fe-rich particles in suspended matter occur mainly as goethite [24]. Scavenging of smaller particles and/or adsorption of soluble species could explain the presence of $\mathrm{Ba}$ and $\mathrm{S}$ in these particles.

- Particles with $\mathrm{Si}-\mathrm{Al}$ as the major constituents. $\mathrm{Fe}, \mathrm{Ca}, \mathrm{Na}$ are occasionally detected. Harmotome, a zeolite reported to occur in the marine environment [25], seems a likely candidate. Depending on their composition $(\mathrm{Si}+\mathrm{Al}+\mathrm{Na}+\mathrm{Ba}$ or $\mathrm{Si}+\mathrm{Al}+\mathrm{Ca}+\mathrm{Ba})$ other particles could represent feldspars. Adsorption

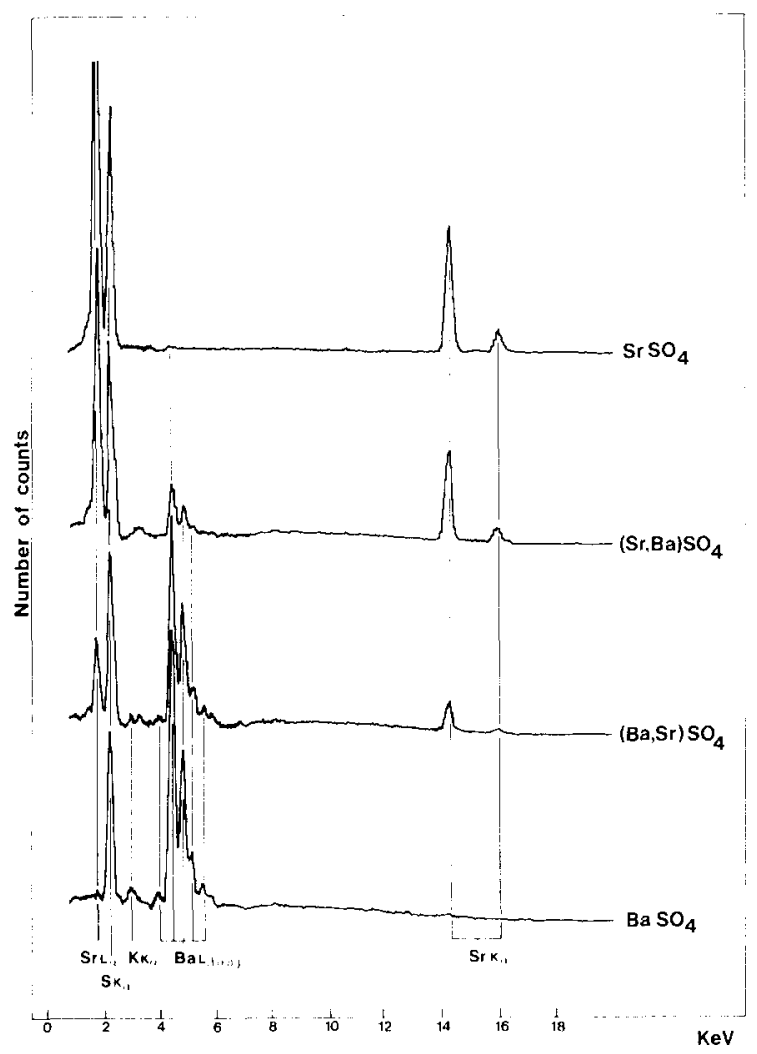

Fig. 4. Energy -dispersive spectra of barite, celestite and intermediate solid solutions, as observed in oceanic suspended matter samples. Vertical scales are arithmetic, but are normalized for the S- $K_{\alpha}$ peak which represents 58,000 counts. Horizontal scale: energies of the X-rays in $\mathrm{keV}$.

processes could explain the presence of the sulphur that is occasionally detected.

\subsection{The size distribution of the barite particles and associated mass of barium (SEM-EMP data)}

According to the method described earlier (p. 531), the barite particle frequency, as a function of particle diameter, and the associated mass of Ba was computed for the samples listed in Table 3. The samples were randomly chosen from one profile in the Argentine Basin (GEOSECS station 67) and two profiles in the North American Basin (GEOSECS station 3 and 5). The barite particle size distributions (e.g., Fig. 7, GEOSECS station 67) are log-normal. This type of 

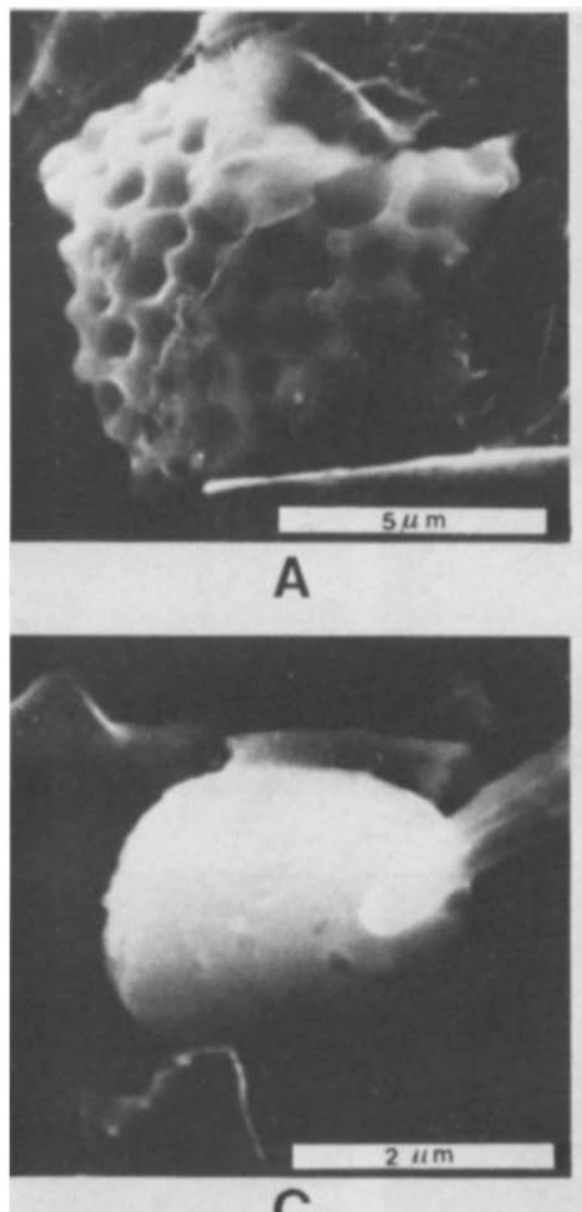

C

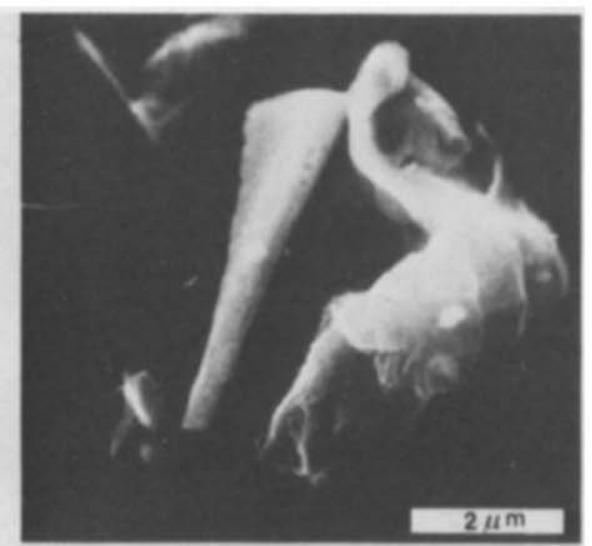

B

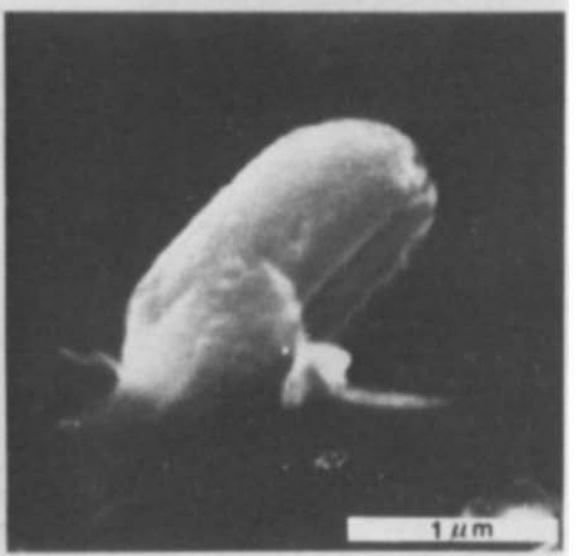

D

Fig. 5. Strontium sulphate and barium-enriched strontium sulphate particles. A. Biogenic $\mathrm{SrO}_{4}$ debris: GEOSECS station 67: $151 \mathrm{~m}$; elemental spectrum by SEM-EMP in Fig. 4, "SrO 4 ". B. Broken $\mathrm{SrSO}_{4}$ spicule: GEOSECS station 67: $62 \mathrm{~m}$; elemental spectrum by SEM-EMP in Fig. 4, "SrSO 4 ". C. Rounded, ellipsoidal (Sr, Ba)SO 4 particle with traces of corrosion: GEOSECS sta-

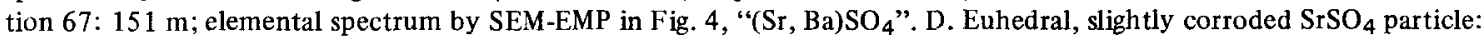
GEOSECS station 67: $1499 \mathrm{~m}$; elemental spectrum by SEM-EMP in Fig. 4, "SrSO 4 ".

distribution is not unusual and has been observed by SEM-EMP in our laboratories for other categories of suspended particles including aluminosilicates [60] and calcareous and siliceous debris $[28,60]$. These size distributions enabled us to compute the mass of Ba carried by suspended barite.

The computed masses of $\mathrm{Ba}$ are given in Table 3 , column B, and are compared with INAA data on total $\mathrm{Ba}_{\mathfrak{p}}$ (Table 3, column $\mathrm{C}$ ).

\section{Discussion}

\subsection{Barite as a genuine component of oceanic sus- pended matter}

The possibility of contamination by Ba-rich particles during the sampling (i.e., contamination with exogenic particles) and the possibility of $\mathrm{BaSO}_{4}$ precipitation due to physical and chemical processes 


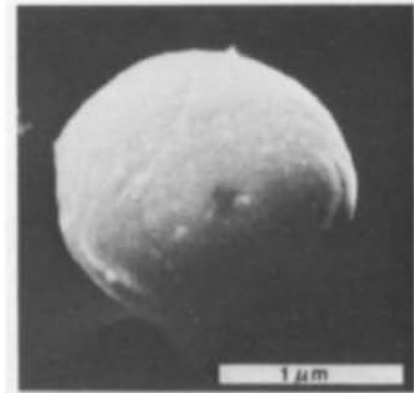

A1

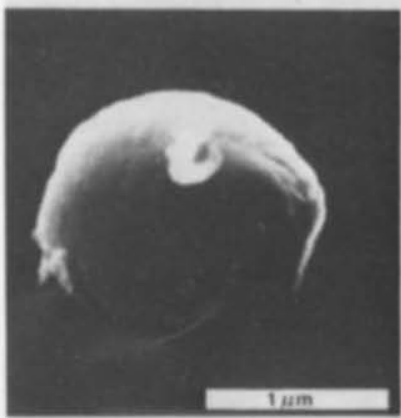

B1

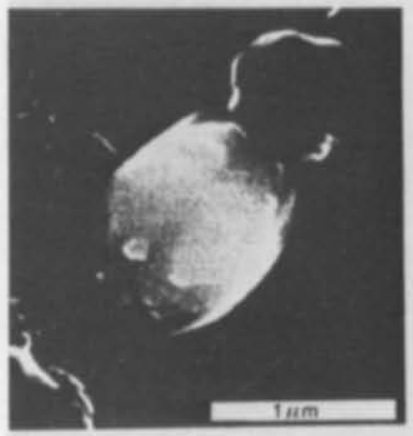

C1

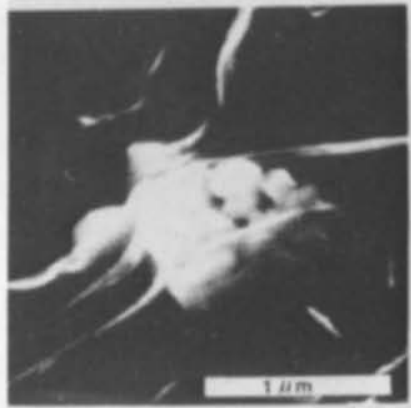

D1

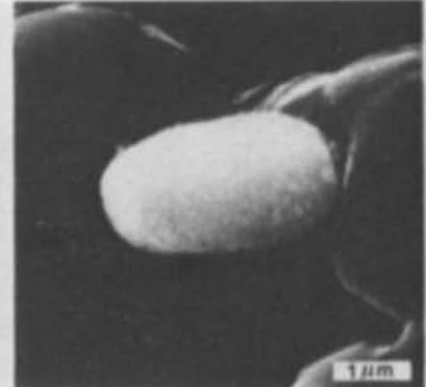

A2

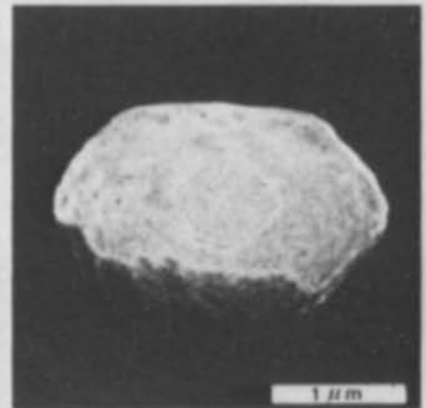

B2

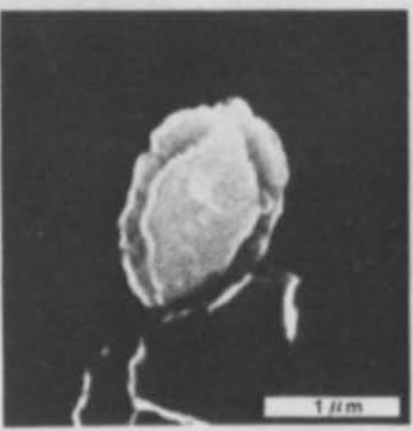

C 2

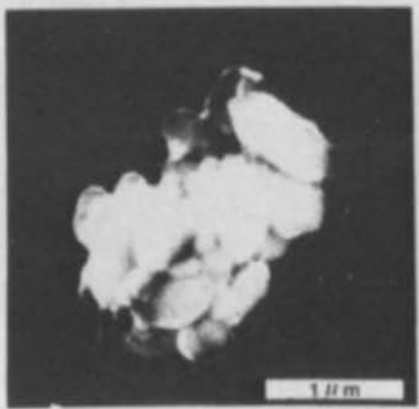

D2

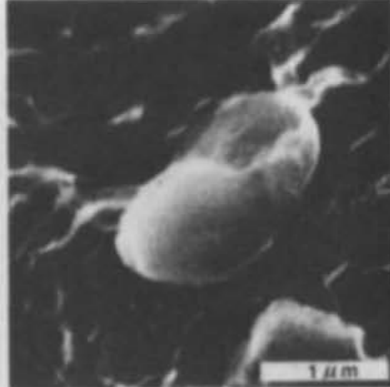

A3

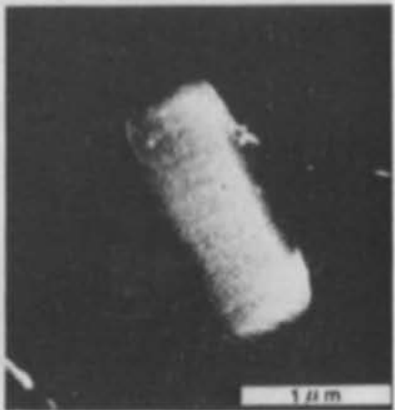

B 3

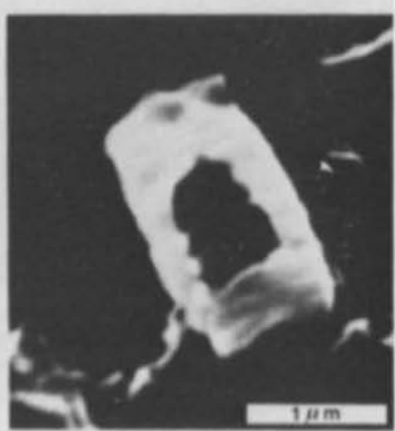

C 3

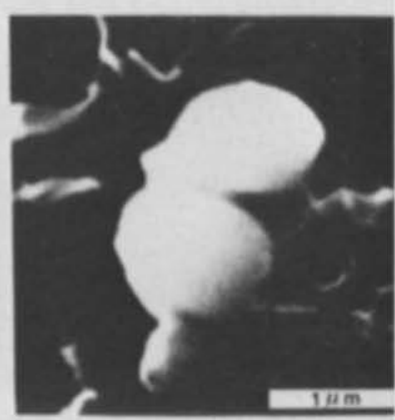

D3

Fig. 6. Morphological types of barite particles in suspension in seawater. A. Ellipsoidal or spherical particles. $1=$ GEOSECS station $67,1499 \mathrm{~m} ; 2$ = GEOSECS station $3,28 \mathrm{~m} ; 3$ = GEOSECS station $82,832 \mathrm{~m}$. B. Particles with a cry stalline habit: euhedral, automorphic particles. 1,2 and 3= GEOSECS station $67,658 \mathrm{~m}, 2982 \mathrm{~m}$, and $2982 \mathrm{~m}$, respectively. C. Irregularly shaped particles; probably affected by dissolution. 1, 2 and $3=$ GEOSECS station 67, $2982 \mathrm{~m}, 2193 \mathrm{~m}$, and $5599 \mathrm{~m}$, respectively. D. Aggregates of very small particles, with or without a crystalline habit. 1,2= GEOSECS station 67, 62 m and 4424 m; $3=$ GEOSECS station 3, $105 \mathrm{~m}$. 
TABLE 3

Comparison between the amount of particulate barium carried by barite particles, measured by SEM-EMP, and the total particulate barium measured by INAA

\begin{tabular}{|c|c|c|c|c|c|c|c|}
\hline \multirow[t]{2}{*}{$\begin{array}{l}\text { Depth } \\
\text { (m) }\end{array}$} & \multicolumn{2}{|c|}{$\begin{array}{l}\text { A } \\
\text { Number of barites }\end{array}$} & \multicolumn{2}{|c|}{$\begin{array}{l}\mathrm{B} \\
\text { Particulate } \mathrm{Ba} \text { in barites }\end{array}$} & \multicolumn{2}{|c|}{$\begin{array}{l}\mathrm{C} \\
\text { Total Bap (INAA data) } \\
\end{array}$} & \multirow{2}{*}{$\begin{array}{l}\text { D } \\
\text { Fraction of total } \\
\mathrm{Ba}_{\mathrm{p}} \text { carried by barit } \\
(\%)\end{array}$} \\
\hline & $(N / \mathrm{kg} \mathrm{sw})$ & $\sigma^{\mathrm{a}}$ & $(\mathrm{ng} / \mathrm{kg} \mathrm{sw})$ & $\sigma^{b}(\%)$ & (ng/kg sw) & $2 \sigma c(\%)$ & \\
\hline \multicolumn{8}{|c|}{ GEOSECS station 67} \\
\hline 151 & 10,600 & 1550 & 10 & 45 & 38.5 & 9 & 25 \\
\hline 353 & 20,400 & 1960 & 48 & 54 & 66.9 & 4 & 72 \\
\hline 658 & 16,580 & 1670 & 27 & 50 & 50.5 & 7 & 53 \\
\hline 1053 & 17,820 & 1760 & 38 & 37 & 50.0 & 6 & 76 \\
\hline 1499 & 12,240 & 1280 & 31 & 44 & 48.2 & 5 & 64 \\
\hline 2193 & 5440 & 670 & 37 & 44 & 37.7 & 4 & 100 \\
\hline 2574 & 7160 & 970 & 27 & 51 & 25.6 & 5 & 100 \\
\hline 2982 & 4180 & 600 & 23 & 78 & 28.2 & 5 & 82 \\
\hline 3601 & 5660 & 1030 & 15 & 59 & 19.2 & 9 & 79 \\
\hline 4424 & 3440 & 490 & 15 & 41 & 19.4 & 9 & 75 \\
\hline 5304 & 8820 & 1260 & 25 & 67 & 33.0 & 13 & 76 \\
\hline \multicolumn{8}{|c|}{ GEOSECS station 3} \\
\hline 105 & 5830 & 580 & 17 & 39 & 27.8 & 9 & 61 \\
\hline 813 & 3900 & 390 & 18 & 53 & 44.2 & 28 & 41 \\
\hline 1083 & 4480 & 630 & 14 & 59 & 16.9 & 17 & 83 \\
\hline 1875 & 25,000 & 2550 & 31 & 36 & 35.1 & 70 & 88 \\
\hline 2479 & 3930 & 410 & 15 & 48 & 18.6 & 14 & 81 \\
\hline 2696 & 1970 & 300 & 5 & 47 & 5.4 & 19 & 93 \\
\hline 2989 & 24,850 & 2740 & 33 & 54 & 33.6 & 17 & 98 \\
\hline 3267 & 2920 & 470 & 15 & 87 & 29.5 & 19 & 51 \\
\hline \multicolumn{8}{|c|}{ GEOSECS station $5 \mathrm{~d}$} \\
\hline 363 & 16,040 & 1830 & 27 & 47 & 36 & & 75 \\
\hline 760 & 46,990 & 5070 & 48 & 40 & 50 & & 96 \\
\hline
\end{tabular}

a $\sigma=1 / \sqrt{ } N$, with $N=$ number of effectively counted barites [23].

b $\sigma=\Sigma \sigma_{i} ; \sigma_{i}=M_{i} / \sqrt{ } n_{i}$, with $M_{i}=\%$ by weight in a given size range; $n_{i}=$ number of particles counted in this size range [23].

c $\sigma$ is determined by the counting statistics in the $166-\mathrm{keV}$ photo-peak region.

$\mathrm{d}_{\text {Total }} \mathrm{Ba}$ data for the samples we analyzed for barite content by SEM-EMP were not available; we deduced total $B \mathrm{a}_{\mathrm{p}}$ values by interpolation of the data of P. Brewer (GEOSECS shore-based data), for depths immediately above and below depths investigated by SEM-EMP.

inherent in the sampling procedure (i.e., contamination with endogenic particles) have been considered and rejected as significant problems. This is based on the following arguments:

Exogenic origin: (1) On board ship, blanks were run under the same technical conditions as the samples. They never show contamination by Ba-rich particles.

(2) Barite particles were observed in all samples collected during various expeditions by different research vessels since 1972. All these samples contain the same morphological types of barite particles. This is incompatible with occurrences of accidental contamination. Furthermore, the use of different equipment for sample collection and handling during GEOSECS, ATLANTIS II, HARMATAN, MIDLANTE and TRANSAT expeditions makes a systematic contamination of the samples unlikely.

(3) On several occasions we observed barite crystals inside low-density pellet-like particles, probably 


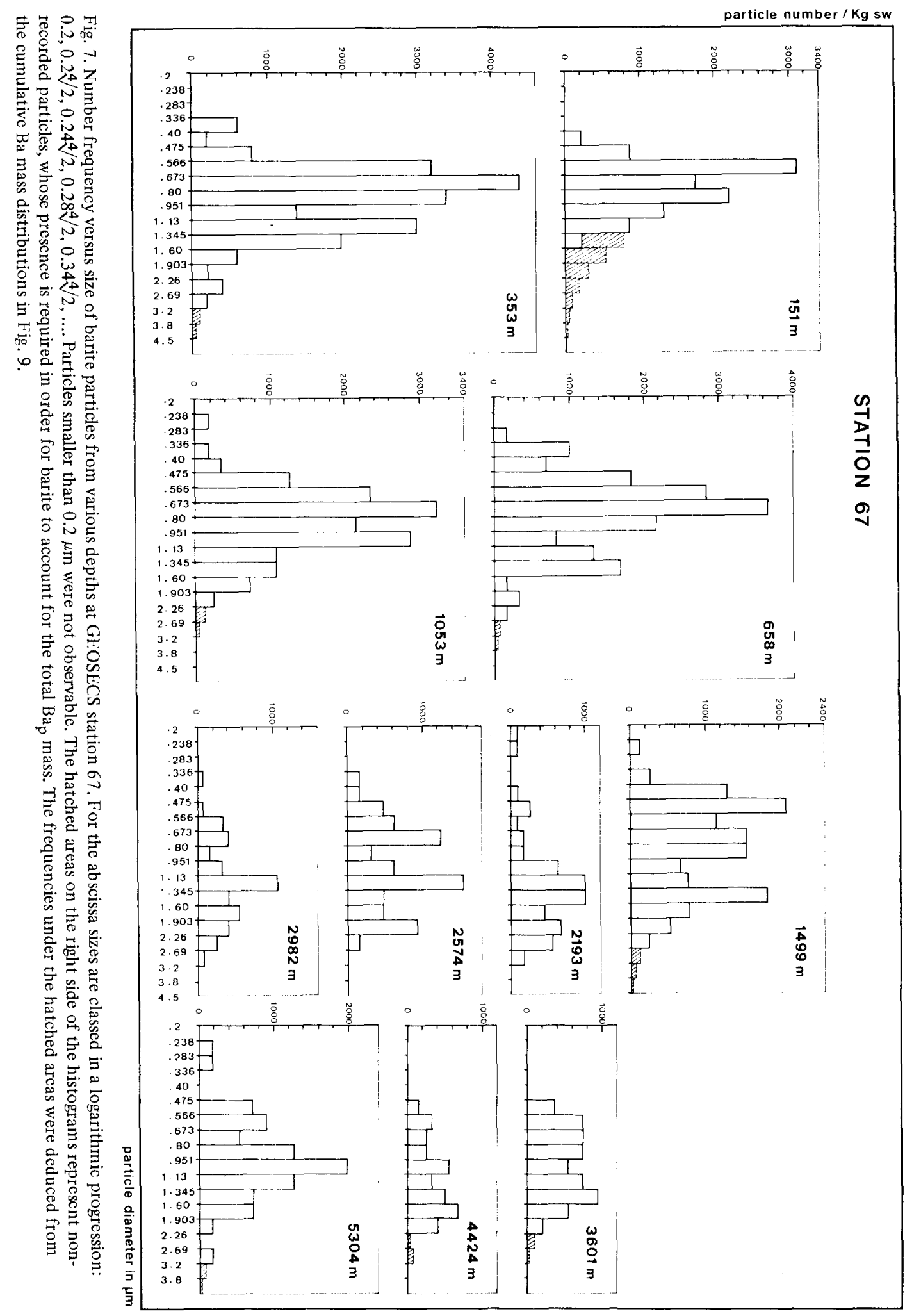




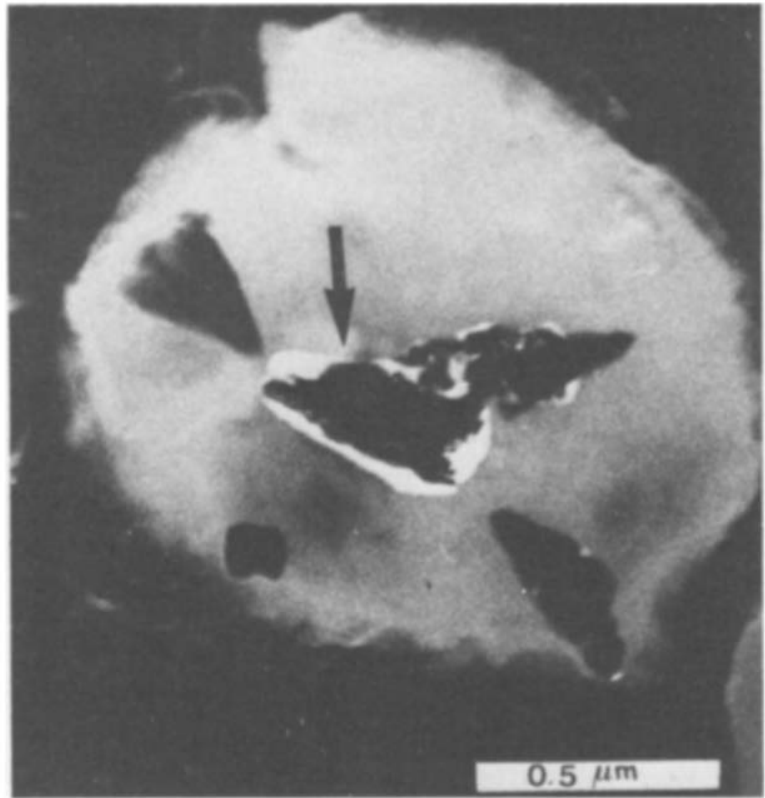

Fig. 8. Dark-field micrograph obtained with a $1-\mathrm{MeV}$ transmission electron microscope of a barite grain (indicated by the arrow) inside an organic pellet, collected at $1860 \mathrm{~m}$ at GEOSECS Pacific station 306. (From J. Klossa, Laboratoire R. Bernas, Orsay and Centre des Faibles Radioactivités, Gifsur-Yvette.)

of organic composition (Fig. 8). Barite particles were also found in large aggregates containing different species of diatoms and coccoliths. These pellets and aggregates represent fragments of the kinds of fecal material described by Bishop et al. [26]. These barite particles were either scavenged by zooplankton and excreted together with the fecal matter, or were formed inside such pellets. An exogenic origin can be excluded in both cases.

Endogenic origin. Several processes can induce a precipitation of barium sulphate during sample recovery:

(1) Deep-sea water samples are enriched in dissolved $\mathrm{Ba}$ and may approach, and eventually reach, saturation when hauled to the surface, since the effects of decompression and temperature transition decrease the saturated $\mathrm{Ba}$ level by a factor two [27]. However, according to Church and Wolgemuth [27] such a precipitation process, especially in heterogenous systems with a large sulphate excess, should take days. Even for the deep-sea samples, recovery time is only a matter of hours. Since deep-sea water Ba concentrations are in fact much lower than the sediment pore waters discussed by Church and Wolgemuth [27], we conclude that barite precipitation does not take place during sample recovery. In fact, barite particles were observed in samples of suspended matter which were filtered in situ, at depths of $2000 \mathrm{~m}$ (ATLANTIS II, station 2111) and $2195 \mathrm{~m}$ (ATLANTIS II, station 715) with an especially designed titanium bottle of the Woods Hole Oceanographical Institution. This technique effectively precludes barite precipitation during sampling.

(2) A possible source of endogenic contamination might be incomplete rinsing of seawater from the filters. The subsequent dessication of such microdrops of seawater can introduce contamination such as precipitated gypsum $\left(\mathrm{CaSO}_{4} \cdot 2 \mathrm{H}_{2} \mathrm{O}\right)[28]$. The complete dessication of about $10 \mu \mathrm{l}$ of seawater is required to obtain the weights of endogenic gypsum, measured by Aubey [28]. If we use this figure $(10 \mu)$ as a reasonable estimate of endogenic sources the maximum amount of $\mathrm{Ba}$ contamination from this mechanism would be $10^{-4} \mu \mathrm{g} /$ filter. This is 1700 times less than the mean total $\mathrm{Ba}_{\mathrm{p}}$ concentration, which consists mainly of barite (section 4.2).

We conclude from the set of arguments presented above that the barite particles we observe are a genuine component of the natural marine environment.

\subsection{Is barite the main carrier of barium in oceanic suspended matter?}

Table 3 compares the calculated mass of barite-Ba (column $\mathrm{B}$ ) with the total $\mathrm{Ba}_{\mathrm{p}}$ measured by INAA on the same filters (column $C$ ), expressed as a percentage (column D). The conclusion that barite is the principal carrier of barium in these samples is inescapable considering the nature and limitations of the method. In 15 cases out of 22 , calculated barite contributions account for over $70 \%$ of the total $\mathrm{Ba}_{\mathrm{p}}$ and for several samples the values are virtually $100 \%$. There are only a couple of cases where the percentage drops below $50 \%$. Part of the Ba amount that is not accounted for by detected barites is certainly carried by phases other than barite (see below). We believe that larger barite grains, which are very scarce and thus 


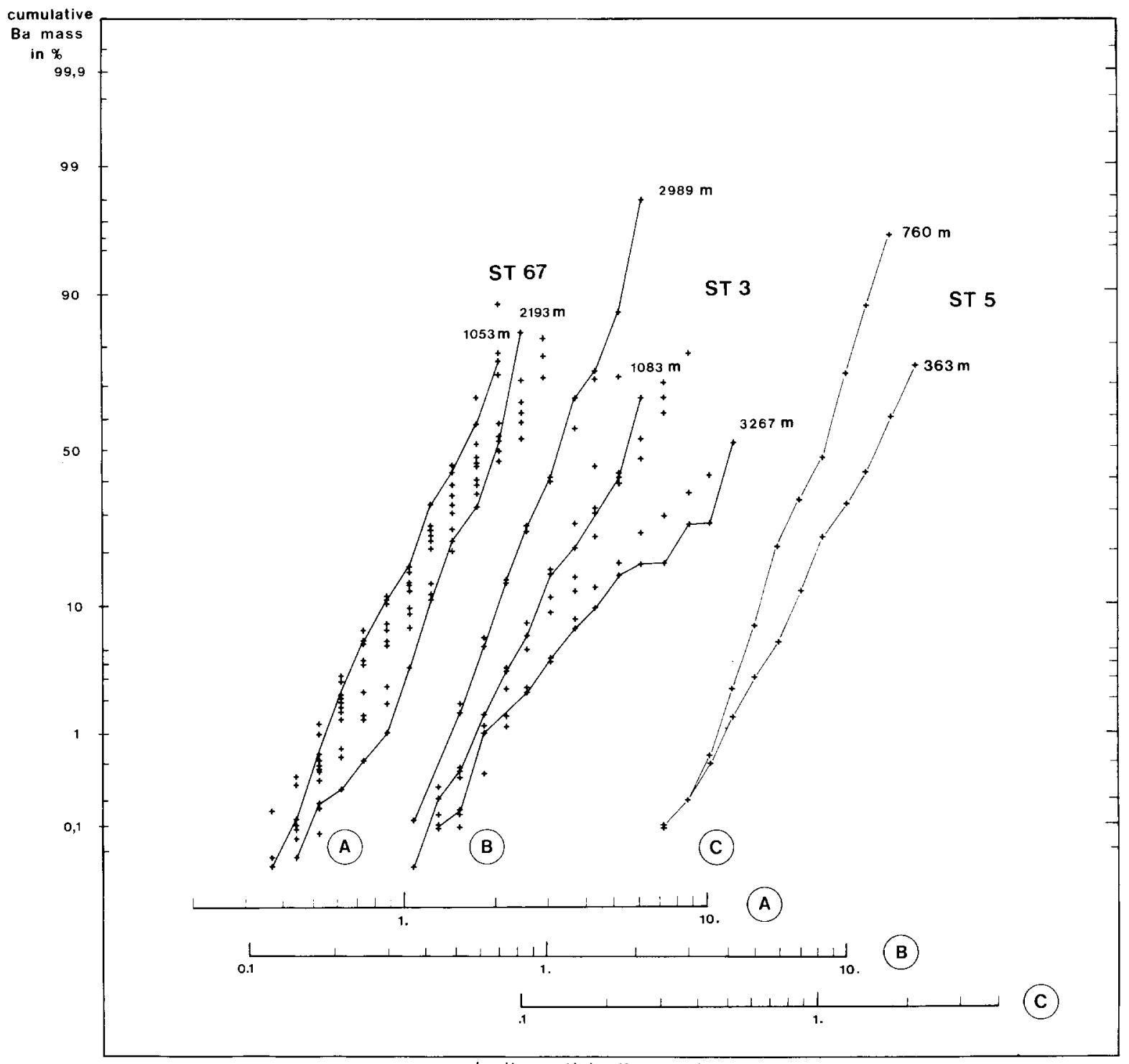

barite particle diameter in $\mu \mathrm{m}$

Fig. 9. Profiles of cumulative Ba mass distributions. Ordinate (gaussian scale): cumulative Ba mass in percent, calculated with respect to the total Bap amount measured by INAA. Abscissa (logarithmic scale: barite particle diameter in microns). Crosses correspond to measured values of cumulated Ba mass (in \%). A = GEOSECS station.67; depth interval 151-5304 m; only the distributions at $1053 \mathrm{~m}$ and $2193 \mathrm{~m}$ are displayed as a solid line. B. GEOSECS station 3; depth interval $105-3267 \mathrm{~m}$; only the distributions at $1083 \mathrm{~m}, 2989 \mathrm{~m}$ and $3267 \mathrm{~m}$ are displayed as a solid line. C. GEOSECS station 5; depth interval 363-760 m; both distributions are displayed as a solid line.

statistically missed during counting procedures, but which have large mass, can account partly for the apparently low percentages in Table 3 , column D. In Fig. 7 we show the projected shape of the tails of the histograms if the cumulative curves of Fig. 9 are extrapolated to $100 \%$. These tails represent the number of large barite grains, which would be required to completely account for the INAA $\mathrm{Ba}_{\mathrm{p}}$ values, if the 
other sources of particulate $\mathrm{Ba}$ are ignored.

The percentage $\mathrm{Ba}_{\mathrm{p}}$ as barite figures are subject to error due to the limitations of the counting, volume estimate and mass extrapolation procedures. There are other carriers of barium in oceanic suspended matter. As discussed in section 4.3, these may account for as little as $8.5 \%$ of the total $\mathrm{Ba}_{\mathrm{p}}$ in intermediate and deep water and as much as $50 \%$ when considering the contributions within the surface waters (first $150 \mathrm{~m}$ ). Within the great bulk of the oceanic water column, however, it is barite which is the dominant carrier of $\mathrm{Ba}_{\mathrm{p}}$.

\subsection{The contribution of non-barite barium carriers to total particulate barium}

The role of diatom skeletons. Several authors [4,10-12], citing the correlation between dissolved $\mathrm{Ba}$ and dissolved $\mathrm{SiO}_{2}$ in the water column and the work of Vinogradova and Koval'skiy [14], have suggested that diatoms play a major role in the transport of Ba. Very few experimental data exist, however, on the uptake of $\mathrm{Ba}$ by diatoms. We have studied this uptake in two diatom species: Rhizosolenia alata and Chaetoceros lauderi. Details concerning the experimental techniques are published elsewhere [29]. The data show that, for $C$. lauderi, Ba uptake does not exceed the INAA detection limit ( $\sim 1$ ppm for these series of analyses). For $R$, alata $\mathrm{Ba}$ is observed to be entirely associated with the silica phase obtained after oxidation of the organic fraction with concentrated peroxide. The Ba uptake is positively related to the Ba content of the growth medium (Table 4).

These $\mathrm{Ba}$ values are 10-100 times smaller, when compared on a whole dry matter basis, than those reported for different Chaetoceros and Rhizosolenia species from the Black Sea by Vinogradova and Koval'skiy [14]. Our data do, however, agree well with those of Martin and Knauer [31] for natural, composite diatom-rich phytoplankton, as well as with the data of Riley and Roth [32] for other cultured diatoms.

The SEM-EMP analyses performed on the diatom frustules in GEOSECS samples show that these frustules contain no $\mathrm{Ba}$ above the detection limit (100-1000 ppm). Therefore we will take the Ba content observed for $R$. alata frustules (120 ppm; Table 4 ), as a representative value for diatom frustules in the ocean.

We use the figure of $10 \%$ as the proportion of biogenic silica in total suspended matter (TSM) ([26,31, $33,34]$; see Table 5 , column B), to calculate the contribution of $\mathrm{Ba}$ from this component in Table 6 , column B.

The role of carbonate skeletons. Biogenic $\mathrm{CaCO}_{3}$ is assumed to contain $200 \mathrm{ppm}$ of $\mathrm{Ba}$ [7], although this is probably an upper limit, since lower values (10-30

\section{TABLE 4}

Barium content (in ppm) of diatoms grown in culture

\begin{tabular}{|c|c|c|c|}
\hline \multirow[t]{2}{*}{ Diatom species } & \multicolumn{2}{|l|}{ Media not enriched in $\mathrm{Ba}$} & \multirow{2}{*}{$\begin{array}{l}\text { Media enriched in } \mathrm{Ba} \\
\text { artificial seawater; dissolved } \\
\text { Ba content: } 30 \mu \mathrm{g} / \mathrm{kg} \mathrm{sw} \mathrm{c}\end{array}$} \\
\hline & $\begin{array}{l}\text { natural seawater; dissolved } \\
\text { Ba content: } 10 \mu \mathrm{g} / \mathrm{kg} \mathrm{sw} \text { a }\end{array}$ & artificial seawater $b$ & \\
\hline Rhizosolenia alata & $\begin{array}{r}58^{d} \\
116^{e}\end{array}$ & $\begin{array}{r}69^{d} \\
138^{e}\end{array}$ & $\begin{array}{l}196^{\mathrm{d}} \\
392^{\mathrm{e}}\end{array}$ \\
\hline Chaetoceros lauderi & $<1$ f & $<1^{f}$ & $<1 \mathrm{f}$ \\
\hline
\end{tabular}

a This value corresponds to the Ba content measured for Mediterranean Sea surface water [30], which is the natural medium in which the diatoms were grown.

$\mathrm{b}$ Ba was introduced into the culture medium as impurities in the constituents used.

c Ba was added as the chloride salt in order to reach a final concentration of $30 \mu \mathrm{g} / \mathrm{kg}$ seawater.

d In ppm of whole dry matter.

e In ppm of $\mathrm{SiO}_{2}$ weight; for $R$. alata the $\mathrm{SiO}_{2}$ weight represents $50 \%$ of the whole dry matter weight. Ba is entirely associated with the silica fraction.

$f$ Concentrations did not exceed the detection limit ( $1 \mathrm{ppm})$. 


\section{TABLE 5}

Concentrations of total suspended matter (TSM), siliceous and calcareous matter, particulate organic matter and aluminosilicates as potential barium carriers in the water column

\begin{tabular}{|c|c|c|c|c|c|}
\hline $\begin{array}{l}\text { Section of the } \\
\text { water column }\end{array}$ & $\begin{array}{l}\text { A } \\
\text { TSM in the } \\
\text { Atlantic } \\
(\mu \mathrm{g} / \mathrm{kg} \mathrm{sw})\end{array}$ & $\begin{array}{l}\mathrm{B} \\
\mathrm{SiO}_{2} \\
(\mu \mathrm{gg} / \mathrm{kw})\end{array}$ & $\begin{array}{l}\mathrm{C} \\
\mathrm{CaCO}_{3} \\
(\mu \mathrm{g} / \mathrm{kg} \mathrm{sw})\end{array}$ & $\begin{array}{l}\text { D } \\
\text { POM } \\
(\mu g / k g s w)\end{array}$ & $\begin{array}{l}\mathrm{E} \\
\text { Alumino- } \\
\text { silicates } \mathrm{e} \\
(\mu \mathrm{g} / \mathrm{kg} \mathrm{sw})\end{array}$ \\
\hline $\begin{array}{l}\text { Surface water } \\
\text { high latitudes } \\
\text { low latitudes } \\
\text { (between } 45^{\circ} \mathrm{N} \text { and } 45^{\circ} \mathrm{S} \text { ) }\end{array}$ & $\begin{array}{l}\max : 200 \\
\max : \quad 50\end{array}$ & $\begin{array}{l}\left(=10 \% \text { of } \operatorname{TSM}^{b}\right) \\
\max : 20 \\
\max : \quad 5\end{array}$ & $\begin{array}{l}\left(=6 \% \text { of } \mathrm{TSM}^{\mathrm{c}}\right) \\
\max : 12 \\
\max : 2\end{array}$ & $\begin{array}{l}\left(=60 \% \text { of } \mathrm{TSM}^{\mathrm{d}}\right) \\
\max : 120 \\
\max : 30\end{array}$ & \} 2.2 \\
\hline $\begin{array}{l}\text { Intermediate and deep water } \\
\text { (high and low latitudes) }\end{array}$ & $\max : 25$ & $\begin{array}{l}\left(=10 \% \text { of } \mathrm{TSM}^{\mathrm{b}}\right) \\
\max : \quad 2.5\end{array}$ & $\begin{array}{l}\left(=6 \% \text { of } \mathrm{TSM}^{\mathrm{c}}\right) \\
\max : 1.5\end{array}$ & $\begin{array}{l}(=60 \% \text { of } \mathrm{TSM} d) \\
\max : 15\end{array}$ & 1.4 \\
\hline $\begin{array}{l}\text { Bottom water } \\
\text { (nepheloid layer) }\end{array}$ & $\begin{array}{l}\text { range: } \\
12-100\end{array}$ & $2.5 \mathrm{f}$ & $1.5^{\mathrm{f}}$ & $15 \mathrm{f}$ & 4.5 \\
\hline
\end{tabular}

a From Brewer et al. [21].

b From Bishop et al. [26], Martin and Knauer [31], Copin-Montegut and Copin-Montegut [33,34].

c From Aubey [28] and CFR-GEOSECS shore-based data.

d From Bishop et al. [26], Copin-Montegut and Copin-Montegut [33,34], Krishnaswami et al. [35].

e From $\mathrm{Al}_{\mathrm{p}}$ geometric means in Buat-Menard and Chesselet [37] and CFR-GEOSECS shore-based data.

f The $\mathrm{CaCO}_{3}$ concentration in bottom water is similar to that in intermediate and deep water (CFR-GEOSECS shore-based data); this is assumed also for $\mathrm{SiO}_{2}$ and POM.

\section{TABLE 6}

Contribution of siliceous and calcareous tests, POM and aluminosilicates to the total barium content of suspended matter

\begin{tabular}{|c|c|c|c|c|c|c|c|c|c|c|}
\hline \multirow[t]{2}{*}{$\begin{array}{l}\text { Section of } \\
\text { the water } \\
\text { column }\end{array}$} & \multirow[t]{2}{*}{$\begin{array}{l}\mathrm{A} \\
\text { Total Bap } \\
(\mathrm{ng} / \mathrm{kg} \mathrm{sw})\end{array}$} & \multicolumn{2}{|c|}{$\begin{array}{l}\mathrm{B} \\
\mathrm{Ba} \text { carried by } \\
\mathrm{SiO}_{2} \text { tests b }\end{array}$} & \multicolumn{2}{|c|}{$\begin{array}{l}\mathrm{C} \\
\mathrm{Ba} \text { carried by } \\
\mathrm{CaCO}_{3} \text { tests } \\
\mathrm{c}\end{array}$} & \multicolumn{2}{|c|}{$\begin{array}{l}\text { D } \\
\text { Ba carried by } \\
\text { POM d }\end{array}$} & \multicolumn{2}{|c|}{$\begin{array}{l}\mathbf{E} \\
\text { Ba carried by } \\
\text { aluminosilicates e }\end{array}$} & \multirow{2}{*}{$\begin{array}{l}\mathrm{F} \\
\text { Fraction of } \\
\text { total Bap carried } \\
\text { by non-barite } \\
\text { phases } \\
(\%)\end{array}$} \\
\hline & & $\begin{array}{l}\text { (ng/kg } \\
\text { sw) }\end{array}$ & $\begin{array}{l}\% \text { of } \\
\text { Bap } \\
\text { total }\end{array}$ & $\begin{array}{l}(\mathrm{ng} / \mathrm{kg} \\
\mathrm{sw})\end{array}$ & $\begin{array}{l}\% \text { of } \\
\mathrm{Ba}_{\mathrm{p}} \\
\text { total }\end{array}$ & $\begin{array}{l}\text { (ng/kg } \\
\text { sw) }\end{array}$ & $\begin{array}{l}\% \text { of } \\
\mathrm{Ba}_{\mathrm{p}} \\
\text { total }\end{array}$ & $\begin{array}{l}(\mathrm{ng} / \mathrm{kg} \\
\text { sw) }\end{array}$ & $\begin{array}{l}\% \text { of } \\
\mathrm{Ba}_{\mathrm{p}} \\
\text { total }\end{array}$ & \\
\hline \multicolumn{11}{|l|}{ Surface water } \\
\hline high latitudes & 27 & 2.4 & 9 & 2.4 & 9 & 7.2 & 27 & \multirow{2}{*}{1.3} & 5 & 50 \\
\hline $\begin{array}{l}\text { low latitudes } \\
\text { (between } 45^{\circ} \mathrm{N} \\
\text { and } 45^{\circ} \mathrm{S} \text { ) }\end{array}$ & 11 & 0.6 & 5.5 & 0.6 & 5.5 & 1.8 & 16.5 & & 12 & 39.5 \\
\hline \multirow{3}{*}{$\begin{array}{l}\text { Intermediate and } \\
\text { deep water } \\
\text { high latitudes } \\
\text { low latitudes } \\
\text { (between } 45^{\circ} \mathrm{N} \\
\text { and } 45^{\circ} \mathrm{S} \text { ) }\end{array}$} & & & & & & & & & & \\
\hline & 27 & \multirow{2}{*}{0.3} & 1 & \multirow{2}{*}{0.3} & 1 & \multirow{2}{*}{0.9} & 3.5 & \multirow{2}{*}{0.8} & 3 & \multirow{2}{*}{$\begin{array}{c}8.5 \\
23\end{array}$} \\
\hline & 10 & & 3 & & 3 & & 9 & & 8 & \\
\hline $\begin{array}{l}\text { Bottom water } \\
\text { (nepheloid layer) }\end{array}$ & 14 & 0.3 & 2 & 0.3 & 2 & 0.9 & 6.5 & 2.7 & 19 & 29.5 \\
\hline
\end{tabular}

\footnotetext{
a From Table 2.

b $\mathrm{SiO}_{2}$ tests contain $120 \mathrm{ppm}$ of $\mathrm{Ba}$; this study (Table 4 ).

c $\mathrm{CaCO}_{3}$ tests contain a maximum of $200 \mathrm{ppm} \mathrm{Ba;} \mathrm{from} \mathrm{Church} \mathrm{[7].}$

d POM contains $60 \mathrm{ppm}$ of Ba; from Martin and Knauer [31], Riley and Roth [32].

e Aluminosilicates contain $600 \mathrm{ppm}$ of Ba; from Turekian [15] and Turekian and Wedepoh1 [38].
} 
ppm) are reported [6] for coccolith oozes. The weight fraction of biogenic $\mathrm{CaCO}_{3}$ in TSM is given in Table 5, column $\mathrm{C}$ and the contribution of $\mathrm{CaCO}_{3}$ skeletons to the total $\mathrm{Ba}_{\mathrm{p}}$ content is shown in Table 6 , column $\mathrm{C}$.

The role of particulate organic matter. Particulate organic matter (POM) represents the main fraction of TSM (Table 5, column D). To estimate the Ba content of this material we have used the data of Riley and Roth [32] and Martin and Knauer [31] for skeleton-free plankton. A mean value of $60 \mu \mathrm{g} \mathrm{Ba} / \mathrm{g}$ dry matter was used to calculate the POM contribution to total $\mathrm{Ba}_{\mathrm{p}}$ in Table 6, column D.

The role of aluminosilicates. SEM-EMP and INAA analyses of GEOSECS suspended matter samples, revealed that $\mathrm{Al}$ can be used as an indicator of aluminosilicates in suspended matter $[24,36,37]$ and confirm estimations of Arrhenius [25] that particulate $\mathrm{Al}$ represents $7-9 \%$ by weight of the total inorganic component of TSM. This quantity is equal to the $\mathrm{Al}$ content of shales: $8 \%$ by weight [38]. We will therefore consider the Ba concentration in shales $(600 \mathrm{ppm}[38,15])$ to be representative of the $\mathrm{Ba}$ content of aluminosilicates suspended in seawater. The aluminosilicate content of seawater is given in Table 5, column $\mathrm{E}$ and the fraction of total $\mathrm{Ba}_{\mathbf{p}}$, carried by aluminosilicates is given in Table 6, column E.

An examination of the data in Table 6, column $\mathrm{F}$ shows that for the largest part of the water column (intermediate and deep water) non-barite phases account for only $8.5-23 \%$ of the total $\mathrm{Ba}_{\mathrm{p}}$. In surface water up to $50 \%$ of total $\mathrm{Ba}$ is carried by phases other than barite. Here skeletal and organic debris are important contributors to the total $\mathrm{Ba}_{\mathrm{p}}$ content of suspended matter. In the bottom nepheloid layer nonbarite phases account for $29.5 \%$ of the total. Here $19 \%$ of total $\mathrm{Ba}_{\mathrm{p}}$ is due to aluminosilicates, most probably resuspended from the sediments in the nepheloid layer [61]. We do not have quantitative measurements for surface and bottom waters, but the remaining fraction of total $\mathrm{Ba}_{\mathrm{p}}$ is most likely comprised of barite particles, which were indeed observed.

\subsection{Origin of the barite particles}

The possibility of direct precipitation of barite in seawater is presently a subject for debate. Seawater is undersaturated with respect to $\mathrm{BaSO}_{4}$ but Hanor [39] has predicted that $\mathrm{Sr}$-enriched barite is less soluble than pure $\mathrm{BaSO}_{4}$ and might precipitate in the sea. Church [7] has shown that this concept cannot be confirmed experimentally. A lack of data on the solid activity coefficients of non-dilute $(\mathrm{Ba}, \mathrm{Sr}) \mathrm{SO}_{4}$ solid solutions prevents the definitive resolution of this problem ([40], and T.M. Church, personal communication, 1979).

Our data lead us to believe that direct precipitation is not a significant process. The highly variable $\mathrm{Sr} / \mathrm{Ba}$ ratios we observe among the barite particles (section 3.2) is inconsistent with authigenic formation of such variable particles in a single parcel of seawater considered as a given physico-chemical environment. In any case we observe Sr-free barites. There is no disagreement between these authors $[7,39]$ concerning the impossibility of inorganic precipitation of barium sulphate under natural oceanic conditions.

Biological activity appears to provide the necessary intermediary for the formation of barite in seawater.

Fig. 10 shows a plot of the mean $\mathrm{Ba}_{\mathrm{p}}$ content versus the mean dissolved $\mathrm{PO}_{4}$ content for a broadly spaced set of stations from the Atlantic Ocean. Since Bap maxima occur at variable depths below the euphotic zone (Fig. 2), all concentrations from $150 \mathrm{~m}$ down to $1000 \mathrm{~m}$ were considered to compute geometric mean values. $\mathrm{PO}_{4}$ values are from GEOSECS ship-board data and the $\mathrm{Ba}_{\mathrm{p}}$ data for GEOSECS stations 27, 5, 11, 18 in the North Atlantic and for GEOSECS station 17 in the Norwegian Sea, are from P. Brewer (GEOSECS shore-based data). A linear relationship between $\mathrm{Ba}_{\mathrm{p}}$ and dissolved $\mathrm{PO}_{4}$ is apparent when considering stations $31,58,27,17,3,5$ and 67 . $\mathrm{PO}_{4}$ contents in surface waters are generally regarded as indicators of potential productivity [41-44] and these results indicate a positive relationship between $\mathrm{Ba}_{\mathrm{p}}$ production and organic productivity. Unfortunately, direct measurements of organic carbon production were not obtained at the same time as the collection of samples for $\mathrm{Ba}$ and $\mathrm{PO}_{4}$. Carbon production data taken at a different period but for the same general vicinity as these stations $[41,44]$ are included in parentheses in Fig. 10. These data confirm the general correlation of $\mathrm{Ba}_{\mathrm{p}}$ with biological productivity. The stations 11, 18, 23 from the Norwegian Sea and the North Atlantic, and station 82, from the Antarctic, fall much closer to the central line when 


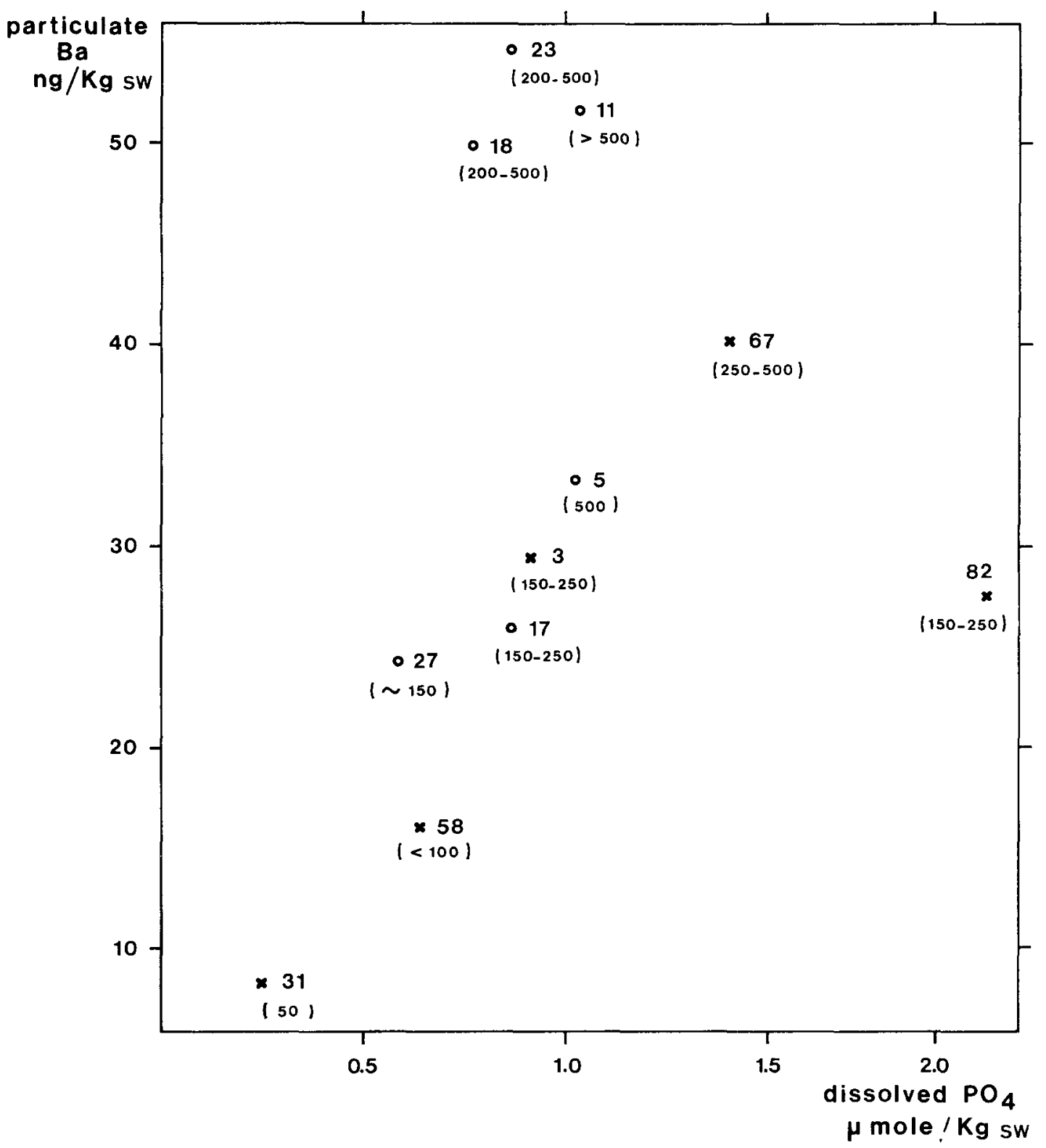

Fig. 10. Total $\mathrm{Ba}_{\mathrm{p}}$ versus dissolved $\mathrm{PO}_{4}$. The geometric mean $\mathrm{Ba}$ value (in $\mathrm{ng} / \mathrm{kg} \mathrm{sw}$ ), observed between 150 and $1000 \mathrm{~m}$ is plotted against the geometric mean dissolved $\mathrm{PO}_{4}$ value (in $\mu \mathrm{mole} / \mathrm{kg}$ sw; GEOSECS ship-board data) for the same depth interval. Crosses refer to $\mathrm{Ba}_{\mathrm{p}}$ measurements performed by INAA at the Centre des Faibles Radioactivités; open circles refer to measurements performed by INAA at the Woods Hole Oceanographical Institution by P. Brewer (GEOSECS shore-based data). Numbers refer to GEOSECS station numbers. Between brackets: values of organic carbon production rates (in $\mathrm{mg} \mathrm{C} / \mathrm{m}^{2} \mathrm{day}$ ) from Koblentz-Mishke [44]; value for station 31 from Steeman-Nielsen [41].

the relative intensity of organic carbon production is considered.

Although this relationship between biological pro- ductivity and barite formation seems to hold, the maximum concentrations of barite are generally found just below the euphotic zone and the detailed pathway 
between organic productivity and barite formation is not known. Two complementary pathways can be considered:

(1) Secretion of barite crystals by planktonic organisms and the release into the waters below the euphotic zone upon the death and disintegration of the organisms. Direct secretion of intracellular barite is known to occur in several species of the benthic protozoan Xenophyophora [45]. In surface waters only $\mathrm{SrSO}_{4}$ (celestite)-secreting organisms, acantharid Radiolaria, have as yet been reported [46]. These, however, have a world-wide distribution and their spines can contain high levels of Ba (up to $5400 \mathrm{ppm}$ ) [25]. The central capsulum of certain species of collosphaerid Radiolaria contain rhombic crystals, identified as celestite and/or barite [47]. Finally, radiolarian-rich plankton has been observed to contain high Ba levels [31]. Such examples indicate that biological mediators can control the varying $\mathrm{Ba} / \mathrm{Sr}$ molar ratios.

(2) Barite is formed during the decomposition of organic matter. Chow and Goldberg [1] proposed that decaying organic matter, rich in sulphate ions, could form a micro-environment in which $\mathrm{BaSO}_{4}$ saturation is attained. We have in fact observed submicron sized, discrete barite crystals and aggregates of barite prisms inside low-density media, of organic composition (Fig. 8). These are likely to represent such micro-environments, with barite precipitated within them. Again, high productivity in the photic zone could thus induce a maximum of suspended barite in the subsurface waters.

\subsection{The importance of suspended barite as a source of deep-sea dissolved $B a$}

Undersaturation with respect to $\mathrm{BaSO}_{4}$ induces the dissolution of suspended barite in the water column.

\subsubsection{Estimation of the dissolution rate of barite in the water column}

We have looked systematically for traces of an etching or corrosion process affecting the barite particles. The morphological study (Fig. 6, section 3.2), revealed that suspended barite particles are nearly all affected, to different degrees, by dissolution. The edges of the euhedral particles are rounded (Fig. 6B, 1-3) and particles become ellipsoïdal and spherical (Fig. 6A, 1-3). Etching of the particles can occur (Fig. 6B, 3). Dissolution proceeds further in eroding the particles by means of a layer by layer alteration (Fig. 6C, 1,2) or by a piercing of the particle (Fig. $6 \mathrm{C}, 3)$. The effect of dissolution is further indicated, at GEOSECS station 67, by the decrease in the numbers of barite particles with depth, as shown in Fig. 7 .

If the dissolution rate constant and the particle size distribution of a substance in the water column are known, and if constancy of particle flux at any depth is assumed, the dissolution rate $J$ can be calculated [48]:

$J=\frac{1}{3} \rho k\left(\Sigma_{i} N_{i} D_{i}^{2}\right)$

where $J=$ input of dissolved matter per unit volume and per unit time $(=\mathrm{g} / \mathrm{kg}$ seawater $\mathrm{yr}) ; \rho=$ density of the particulate matter $\left(=4.5 \mathrm{~g} / \mathrm{cm}^{3}\right.$ for barite $) ; k=$ dissolution rate constant $(\mathrm{cm} / \mathrm{yr})(=\epsilon \pi$ in equation 9 in Lal and Lerman [48]); $N_{i}=$ particle number in size class $i$, per unit volume (number $/ \mathrm{kg}$ seawater); and $D_{i}=$ particle diameter; = class-midpoint of class $i$ $(\mathrm{cm})$.

The dissolution rate constant of barite was estimated from a comparative study of the size distributions of barite for successive samples in the water column. It was assumed that the sinking particles obey the Stokes settling and dissolution rate model proposed by Brun-Cottan [49] after an original model of Lal and Lerman [50]. The sample pairs for which it was possible to apply the model calculations are given in Table 7A, together with the derived dissolution rate constants $(k)$. An order of magnitude difference exists between the lowest and the highest computed values of $k$. If barite dissolution is a surface-controlled process, as observed for other sulphate salts [51], the lower range of $k$ values $(0.05$ and $0.1 \mu \mathrm{m} / \mathrm{yr}$ ) is more compatible with the existing condition of low undersaturation for $\mathrm{BaSO}_{4}$ in deep water, as discussed in Dehairs [29]. Therefore we have used an average $k$ value of $0.075 \mu \mathrm{m} / \mathrm{yr}$. Equation (2) was applied to all the barite size distributions of GEOSECS stations 67 and 3, and a depth-weighted $J_{\mathrm{Ba}}$ value was deduced. Table $7 \mathrm{~B}$ shows the best estimate of $J_{\mathrm{Ba}}$ resulting from the dissolution of suspended barites identified in this study.

Since carriers of Ba other than barite exist, and 


\section{TABLE 7A}

Dissolution rate constants of barite as deduced from a Stokes settling and dissolution rate model

\begin{tabular}{ll}
\hline $\begin{array}{l}\text { Stations and } \\
\text { considered sample pairs }\end{array}$ & $\begin{array}{l}\text { Barite dissolution rate } \\
\text { constant } k \\
(\mu \mathrm{m} / \mathrm{yr})\end{array}$ \\
\hline $67(2574-2982 \mathrm{~m})$ & 0.05 \\
$3(1975-2479 \mathrm{~m})$ & 0.1 \\
$3(2989-3267 \mathrm{~m})$ & 0.4 \\
\hline
\end{tabular}

TABLE 7B

Depth weighted $J_{\mathrm{Ba}}$ values for the GEOSECS stations 67 and 3 , resulting from barite dissolution

\begin{tabular}{ll}
\hline $\begin{array}{l}\text { Stations and } \\
\text { considered depth } \\
\text { interval }\end{array}$ & $\begin{array}{l}J_{\mathrm{Ba}}(\text { depth-weighted }) \text { for } \\
k=0.075 \mu \mathrm{m} / \mathrm{yr} \\
\left(\mu \mathrm{g} / \mathrm{cm}^{2} \mathrm{yr}\right)\end{array}$ \\
\hline $67(151-5304 \mathrm{~m})$ & 0.42 \\
$3(105-3267 \mathrm{~m})$ & 0.36 \\
\hline
\end{tabular}

since these are not conservative, we must also estimate the contribution of their dissolution to the overall $J_{\mathrm{Ba}}$ term.

\subsubsection{The $J_{\mathrm{Ba}}$ flux resulting from the dissolution of $\mathrm{SiO}_{2}$ and $\mathrm{CaCO}_{3}$ skeletons}

$J_{\mathrm{CaCO}_{3}}$ and the resulting $J_{\mathrm{Ba}}$. We take $\mathrm{CaCO}_{3}$ and particulate organic carbon (POC; $=1 / 2 \times$ POM [52]) to represent, respectively, 6 and $30 \%$ by weight of TSM (Table 5) and consider a mean Atlantic Ocean organic $C$ production rate of $7 \mathrm{mg} / \mathrm{cm}^{2}$ yr [44]. By $\left[\mathrm{CaCO}_{3}\right] /[\mathrm{POC}] \times$ production rate of organic $\mathrm{C}$, we obtain a mean $\mathrm{CaCO}_{3}$ production rate of $1.4 \mathrm{mg} / \mathrm{cm}^{2}$ yr. If an average $\mathrm{CaCO}_{3}$ sedimentation rate of 0.34 $\mathrm{mg} / \mathrm{cm}^{2} \mathrm{yr}$ is considered [43], it follows that about $80 \%\left(=1.1 \mathrm{mg} / \mathrm{cm}^{2} \mathrm{yr}\right)$ of the $\mathrm{CaCO}_{3}$ produced in the surface reservoir redissolves at depth. This $J_{\mathrm{CaCO}_{3}}$ agrees with data of Berger ([43]: $1.5 \mathrm{mg} / \mathrm{cm}^{2} \mathrm{yr}$ ) and $\mathrm{Li}$ et al. ([53] : $\left.1.7 \mathrm{mg} / \mathrm{cm}^{2} \mathrm{yr}\right)$.

Since the $\mathrm{Ba}$ content of $\mathrm{CaCO}_{3}$ skeletons was assigned an upper limit of $200 \mathrm{ppm}$ (section 4.3), the $J_{\mathrm{Ba}}$ resulting from the dissolution of carbonate debris is $\leqslant 0.22 \mu \mathrm{g} / \mathrm{cm}^{2} \mathrm{yr}$.
$J_{\mathrm{SiO}_{2}}$ and the resulting $J_{\mathrm{Ba}}$. We take silica to represent $10 \%$, and POC $30 \%$, of the weight of TSM (Table 5). By $\left[\mathrm{SiO}_{2}\right] /[\mathrm{POC}] \times$ production rate of organic $\mathrm{C}$ (with $P O C$ and $C$ production rate values as given above), it ensues that biogenic silica production is 2.3 $\mathrm{mg} / \mathrm{cm}^{2} \mathrm{yr}$. This value is higher than that computed by Berger ([43]: $\left.1.3 \mathrm{mg} / \mathrm{cm}^{2} \mathrm{yr}\right)$ but is in agreement with the value of Harriss ([54]:2.1 mg/cm ${ }^{2} \mathrm{yr}$ ). The dissolution of opal at depth can amount to $97 \%$ of the quantity produced in surface waters [55]. With silica tests containing $120 \mathrm{ppm}$ of $\mathrm{Ba}$ (section 4.3), their dissolution results in a $J_{\mathrm{Ba}}$ of $0.28 \mu \mathrm{g} / \mathrm{cm}^{2}$ yr.

Summarizing, the overall $J_{\mathrm{Ba}}\left(0.9 \mu \mathrm{g} / \mathrm{cm}^{2} \mathrm{yr}\right)$ is composed of $J_{\mathrm{Ba}}$-barite $\left(0.4 \mu \mathrm{g} / \mathrm{cm}^{2} \mathrm{yr}\right) ; J_{\mathrm{Ba}}-\mathrm{SiO}_{2}$

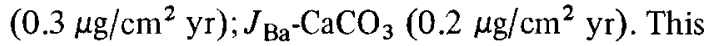
overall $J_{\mathrm{Ba}}$ value is in closer agreement with that calculated using a vertical advection diffusion model in the Pacific Ocean $\left(0.7 \mu \mathrm{g} / \mathrm{cm}^{2}\right.$ yr) [56], than with that deduced by box-model calculations $\left(3.5 \mu \mathrm{g} / \mathrm{cm}^{2} \mathrm{yr}\right)$ $[3,4]$.

We agree with the conclusions of Chan et al. [2] that the distribution of dissolved $\mathrm{Ba}$ is governed by the dissolution of a slowly dissolving phase. Our data show that each of the phases suggested by Chan et al. (barite-carbonate-silica) is of about equal importance.

\subsection{The role of suspended barite in the accumulation of barium in the sediments}

Church [7] showed that in areas of rapid carbonate deposition, the barium accumulation associated with carbonate, clay, and organic matter, was sufficient to account for the observed levels of barite in the sediments. The biogenic particulate matter accumulating in the sediments is likely to have been conveyed by fast-settling fecal material $[26,35,57$, $58,62]$. Due to its high settling velocity, it is likely that most of this fecal material arrives intact at the sediments. The associated flux of barium was calculated by considering $\mathrm{POM}, \mathrm{SiO}_{2}$ and $\mathrm{CaCO}_{3}$ to contain 60,120 and 200 ppm of Ba respectively ( $\mathrm{Ta}$ ble 6), and using the Bishop et al. [62,26] flux data for these main components, obtained for the Equatorial Atlantic [26] and the Cape Basin [62]. The resulting fecal matter flux of $\mathrm{Ba}$ amounts to between 0.03 and $0.5 \mu \mathrm{g} / \mathrm{cm}^{2}$ yr.

It is likely that this flux is supplemented by a conservative flux of suspended barite. The upper limit of 
this flux can be computed from our size distribution data as given in Fig. 7, assuming Stokes settling law, by solving:

$B=\sum_{i} m_{i} v_{i}$

where $B=$ vertical flux of barite $\left(\mu \mathrm{g} \mathrm{Ba} / \mathrm{cm}^{2} \mathrm{yr}\right) ; m_{i}=$ Ba concentration $\left(\mu \mathrm{g} / \mathrm{cm}^{3}\right)$ of barite in size class $i$; and $v_{i}=$ Stokes settling velocity of the barites of size $i(\mathrm{~cm} / \mathrm{yr})$.

As applied to the deep-sea samples of the stations 67 and 3, equation (3) gives: station $67,5304 \mathrm{m:} B=$ $0.4 \mu \mathrm{g} \mathrm{Ba} / \mathrm{cm}^{2} \mathrm{yr}$; station 3, $3267 \mathrm{m:} B=0.4 \mu \mathrm{g} \mathrm{Ba} /$ $\mathrm{cm}^{2}$ yr. Assuming that such fluxes reach the sediments, it appears that settling of suspended barite can at least be as important as $\mathrm{Ba}$ associated with the flux of fecal material. The total Ba flux (fecal material + barite) amounts to between 0.43 and $0.9 \mu \mathrm{g} \mathrm{Ba} / \mathrm{cm}^{2}$ $\mathrm{yr}$, which is in agreement with the sedimentary $\mathrm{Ba}$ accumulation rate of Turekian $([15,59]: 0.5-1.0 \mu \mathrm{g} /$ $\mathrm{cm}^{2} \mathrm{yr}$ ).

The total flux of particulate barium to the sediments computed here appears to balance the amount of dissolved $\mathrm{Ba}$ introduced to the oceans by river discharge $\left(0.6 \mu \mathrm{g} / \mathrm{cm}^{2} \mathrm{yr}\right)[3,4,56]$. Adding to this the barium reintroduced to the dissolved phase $(0.9 \mu \mathrm{g})$ $\mathrm{cm}^{2} \mathrm{yr}$ ), the rate of particulate Ba production (A) should amount to about $1.5 \mu \mathrm{g} / \mathrm{cm}^{2}$ yr to maintain steady state. A rough calculation, assuming that all of the barium in the annual production of that POM which is not lost to the sediments $\left(0.8 \mu \mathrm{g} \mathrm{Ba} / \mathrm{cm}^{2} \mathrm{yr}\right)$ is converted to barite, and adding the annual incorpo-

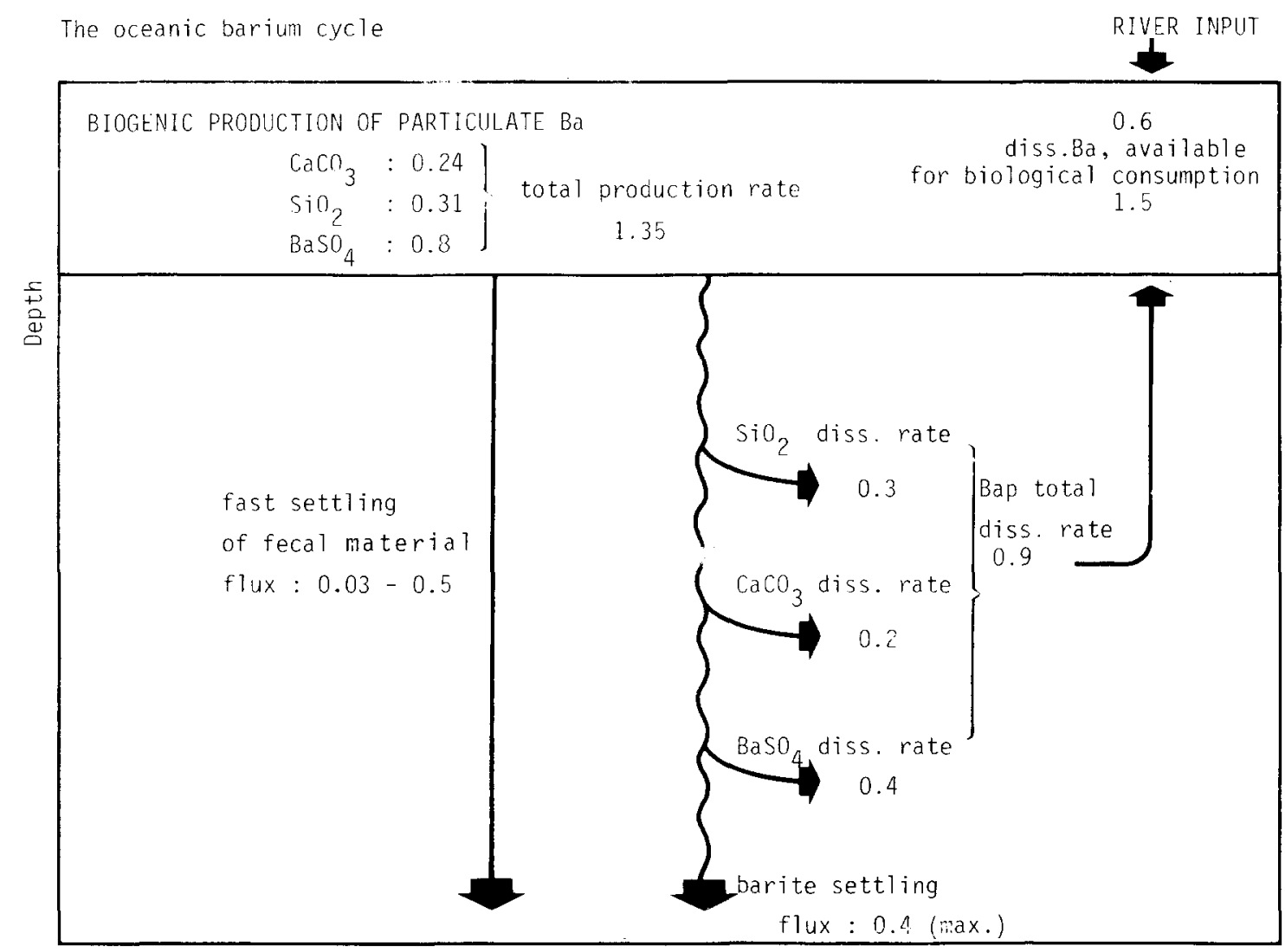

Sedimentary Ba accumulation rate : $0.5-1.0$.

Fig. 11. Numerical values for the components of the oceanic barium cycle. All values in $\mu \mathrm{g} \mathrm{Ba} / \mathrm{cm}^{2} \mathrm{yr}$. Arrows indicate the direction of the fluxes. 
ration of barium into skeletal material $\left(0.55 \mu \mathrm{g} / \mathrm{cm}^{2}\right.$ $\mathrm{yr}$ ), gives a figure (B) of $1.35 \mu \mathrm{g} / \mathrm{cm}^{2} \mathrm{yr}$. The agreement between $A$ and $B$ affirms the importance of biological activity and the recycling of barium in the water column. Fig. 11 summarizes the gross budget of barium in the ocean, as based on our data.

\section{Summary and conclusions}

Discrete micron-sized barite particles are present in suspended matter everywhere in the World Ocean.

A combination, in the same suspended matter samples, of quantitative analyses of the total barium content and quantitative assessments of the numbers and mass of $\mathrm{Ba}$ of the discrete barite particles, show that barite is the main carrier of $\mathrm{Ba}$ in intermediate and deep ocean waters. In surface waters organic and skeletal debris comprise a significant portion of the total particulate barium. In bottom waters resuspended aluminosilicates can dominate over other forms of non-barite particulate barium.

The repartition of Ba between organic, skeletal and barite phases indicates that barite is first introduced in surface waters by biological processes, and that such processes subsequently lead to barite maxima in intermediate waters.

The link between barite production and biological activity is emphasized by a positive relationship between the particulate barium content in surface waters and biological productivity. The kinds of processes which may be responsible are: direct secretion of barite within planktonic organisms, and precipitation within the micro-environments of decaying organic debris.

Dissolution of barite in the deep ocean proceeds at a rate of $0.4 \mu \mathrm{g} \mathrm{Ba} / \mathrm{cm}^{2} \mathrm{yr}$. A supplementary flux, which is of the same magnitude, is the flux of dissolved barium resulting from the dissolution of $\mathrm{SiO}_{2}$ and $\mathrm{CaCO}_{3}$ tests.

The residual flux of barite reaching the sea floor can account for half of the total sedimentation rate of barium in regions of high productivity.

The budget for barium in the ocean, as derived from our data, affirms the importance of biological activity. This budget is to a large degree self-sustained by the input to the water column of dissolved barium resulting from the dissolution of suspended barite and other biogenic particles.

\section{Acknowledgements}

This work could not have been achieved without the assistance of C.E. Lambert for the neutron activation analyses, of J.C. Brun-Cottan for the interpretation of the size distribution data, of J. Klossa in obtaining the electron diffractograms and of C. Jehanno for the scanning electron microscope and electron microprobe analyses. We are very grateful to $T$. Church, P. Biscaye, P. Buat-Menard, D. Spencer, P. Brewer, R. Wollast and A. Herbosch for their fruitful discussions and suggestions. We also wish to thank the three anonymous reviewers, as well as D. Losman and N. Silverberg for the suggested improvements of the initial manuscript. We are indebted to the GEOSECS Operations Group and especially to A. Bainbridge for providing the suspended matter samples, and to the Laboratoire d'Analyses par Activation "Pierre Sue", CNRS-CEA, Centre d'Etudes Nucléaires, Saclay, France, for providing the facilities for neutron activation analysis. This work was supported by a GEOSECS-NSF grant, through subcontracts with the Woods Hole Oceanographical Institution (19721973), Columbia University (1974-1975), and the University of Miami (1976-1977).

\section{References}

1 T.J. Chow and E.D. Goldberg, On the marine geochemistry of barium, Geochim. Cosmochim. Acta 20 (1960) 192.

2 L.H. Chan, D. Drummond, J.M. Edmond and B. Grant, On the barium data from the Atlantic GEOSECS expedition, Deep-Sea Res. 24 (1977) 613.

$3 \mathrm{~K}$. Wolgemuth and W.S. Broecker, Barium in sea water, Earth Planet. Sci. Lett. 8 (1970) 372.

4 Y.H. Li, T.L. Ku, G.G. Mathieu and K. Wolgemuth, Barium in the Antarctic Ocean and implications regarding the marine geochemistry of $\mathrm{Ba}$ and ${ }^{226} \mathrm{Ra}$, Earth Planet. Sci. Lett. 19 (1973) 352.

5 E. Goldberg and G. Arrhenius, Chemistry of pelagic sediments, Geochim. Cosmochim. Acta 33 (1969) 894.

6 K.K. Turekian and E.H. Tausch, Barium in deep-sea sediments of the Atlantic Ocean, Nature 201 (1964) 696.

7 T.M. Church, Marine barite, Ph.D. Thesis, University of California (1970).

8 J.S. Hanor, Rates of barium accumulation in the Equatorial Pacific, Geol. Soc. Am., Abstr. Progr. 4 (1972) 526.

9 K. Boström, O. Joensuu, C. Moore, B. Boström, M. Dalziel and A. Horowitz, Geochemistry of barium in pelagic sediments, Lithos 6 (1973) 159. 
10 T.L. Ku, Y.H. Li, G.G. Mathieu and H.K. Wong, Radium in the Indian-Antarctic Ocean south of Australia, J. Geophys. Res. 75 (1970) 5286.

11 J.M. Edmond, Comments on the paper by T.L. Ku, Y.H. Li, G.G. Mathieu and H.K. Wong, "Radium in the IndianAntarctic Ocean south of Australia", J. Geophys. Res. 75 (1970) 6878.

12 M.P. Bacon and J.M. Edmond, Barium at GEOSECS III in the Southeast Pacific, Earth Planet. Sci. Lett. 16 (1972) 66.

$13 \mathrm{M}$. Brongersma-Sanders, Barium in pelagic sediments and in diatoms, K. Ned. Akad. Wet. Proc. B70 (1966) 93.

14 Z.A. Vinogradova and V.V. Koval'skiy, Elemental composition of the Black Sea plankton, Dokl. Akad. Nauk USSR, Earth Sci. Sect. 147 (1962) 217.

15 K.K. Turekian, Deep-sea deposition of barium, cobalt and silver, Geochim. Cosmochim. Acta 32 (1968) 603.

16 F.E. Schulze and H. Thierfelder, Bariumsulfat in Meerestieren (Xenophyophora, F.E. Sch.), Sitzungsber. Ges. Naturforsch. Freunde Berlin (1905) 2.

17 G. Arrhenius and E. Bonatti, Neptunism and vulcanism in the ocean, in: Progress in Oceanography, 3, F. Koczy, ed. (1965) 7.

18 C. Darcourt, Etude des matières en suspension dans les eaux profondes Atlantiques: teneurs en éléments traces mesurées par activation neutronique, comparaisons avec le sédiment, Thèse Doct. 3è Cycle, Université de Paris 6 (1973).

19 R. Chesselet, J. Jedwab, C. Darcourt and F. Dehairs, Barite as discrete suspended particles in the Atlantic Ocean, EOS, Am. Geophys. Union 57 (1976) 255 (abstract).

20 D.W. Spencer, P.G. Brewer, R. Chesselet, P.E. Biscaye and J. Jedwab, Dissolution and composition of suspended matter in the Atlantic Ocean, Abstr. IUGG Assem., Grenoble (1975).

21 P.G. Brewer, D.W. Spencer, P.E. Biscaye, A. Hanley, P.L. Sachs, C.L. Smith, S. Kadar and J. Fredericks, The distribution of particulate matter in the Atlantic Ocean, Earth Planet. Sci. Lett. 32 (1976) 393.

22 J. Klossa, Contribution à l'étude de la matière particulaire par une méthode d'analyses ponctuelles combinées, Thèse Doct. 3è Cycle, Université de Paris 6 (1977).

23 T. Allen, Particle Size Measurement (Chapman and Hall, London, 1968).

24 C.F. Lambert, Contribution à l'étude du fer et de l'aluminium particulaires dans l'océan, Thèse de diplôme d'Etudes supérieures, Université de Picardie (1979).

25 G. Arrhenius, Pelagic sediments, in: The Sea, 3, M.N. Hill, ed. (Wiley-Interscience, New York, N.Y., 1963) 655.

26 J.K. Bishop, J.M. Edmond, D.R. Ketten, M.P. Bacon and W.B. Silker, The chemistry, biology and vertical flux of particulate matter from the upper $400 \mathrm{~m}$ of the Equatorial Atlantic Ocean, Deep-Sea Res. 24 (1977) 511.

27 T.M. Church and K. Wolgemuth, Marine barite saturation, Earth Planet. Sci. Lett. 15 (1972) 35.

28 O. Aubey, Contribution à l'étude de la dissolution des particules de carbonate de calcium dans les eaux profondes océaniques, Thèse 3è Cycle, Université de Paris 6 (1976).
29 F. Dehairs, Discrete suspended particles of barite and the barium cycle in the open ocean, Doctoral Thesis in Science, Vrije Universiteit, Brussels (1979).

$30 \mathrm{H}$. Bernat, T. Church and C.J. Allègre, Barium and strontium concentrations in Pacific and Mediterranean seawater profiles by direct isotope dilution mass spectrometry, Earth Planet. Sci. Lett. 16 (1972) 75.

31 J. Martin and G.A. Knauer, The chemical composition of plankton, Geochim. Cosmochim. Acta 37 (1973) 1639.

32 J.P. Riley and I. Roth, The distribution of trace elements in some species of phytoplankton grown in culture, $\mathrm{J}$. Mar. Biol. Assoc. U.K. 51 (1971) 63.

33 C. Copin-Montegut and G. Copin-Montegut, Chemical analysis of suspended particulate matter collected in the northeast Atlantic, Deep-Sea Res. 19 (1972) 445.

34 C. Copin-Montegut and G. Copin-Montegut, The chemistry of particulate organic matter from the south Indian and Antarctic Ocean, Deep-Sea Res. 25 (1978) 911.

35 S. Krishnaswami, D. Lal and B.L.K. Somayajulu, Investigations of gram quantities of Atlantic and Pacific surface particulates, Earth Planet. Sci. Lett. 32 (1976) 403.

36 R. Chesselet, D.W. Spencer and P.E. Biscaye, Element transport by particles: the aluminium, manganese, iron system in Atlantic suspended matter, in: Book of Abstracts, Geochemistry and Ocean Mixing Symposium, Joint Oceanographic Assembly, Edinburgh 1976 (F.A.O., Rome, 1976).

37 P. Buat-Menard and R. Chesselet, Variable influence of the atmospheric flux on the trace metal chemistry of oceanic suspended matter, Earth Planet. Sci. Lett. 42 (1979) 399.

38 K.K. Turekian and K.H. Wedepohl, Distribution of the elements in some major units of the Earth's crust, Geol. Soc. Am. Bull. 72 (1961) 175.

39 J.S. Hanot, Barite saturation in sea water, Geochim. Cosmochim. Acta 33 (1969) 894.

40 T.M. Church, Barium sulfate solubility in seawater (submitted to Earth Planet. Sci. Lett.).

41 E. Steeman-Nielsen, On organic production in the oceans, J. Cons., Int. Explor. Mer 19 (1954) 309.

42 J.L. Reid, On circulation, phosphate-phosphorus content, and zooplankton volumes in the upper part of the Pacific Ocean, Limnol. Oceanogr. 7 (1962) 287.

43 W.H. Berger, Biogenous deep-sea sediments; fractionation by deep-sea circulation, Geol. Soc. Am. Bull. 81 (1970) 1385.

44 O.J. Koblentz-Mishke, V.V. Volkovinsky and J.G. Kabanova, Plankton primary production of the world ocean, in: Scientific Exploration of the South Pacific, W.S. Wooster, ed. (U.S. National Academy of Science, Washington, D.C., 1970) 183.

45 O.S. Tendal, A monograph of the Xenophyophoria, Galathea Rep. 12 (1972) 8.

46 E.M. Botazzi and B. Schreiber, Acantharia in the Atlantic Ocean, their abundance and preservation, Limnol. Oceanogr. 16 (1971) 677.

47 E. Haeckel, Radiolarien (Rhizopoda Radiolaria), Eine Monographie (G. Reimer Verlag, Berlin, 1862). 
48 D. Lal and A. Lerman, Dissolution and behaviour of particulate biogenic matter in the ocean: some theoretical considerations, J. Geophys. Res. 78 (1973) 7100.

49 J.C. Brun-Cottan, Stokes settling and dissolution rate model for marine particles as a function of size distribution, J. Geophys. Res. 81 (1976) 1601.

50 D. Lal and A. Lerman, Size spectra of biogenic particles in ocean water and sediments, J. Geophys. Res. 80 (1975) 423.

51 J.R. Campbell and G.H. Nancollas, The crystallization and dissolution of strontium sulfate in aqueous solution, J. Phys. Chem. 73 (1969) 1735.

52 J.D.H. Strickland, Production of organic matter in the primary stages of the marine food chain, in: Chemical Oceanography, 2, J.P. Riley and G. Skirrow, eds. (Academic Press, New York, N.Y., 1965) 477.

53 Y.H. Li, T. Takahashi and W.S. Broecker, Degree of saturation of $\mathrm{CaCO}_{3}$ in the oceans, J. Geophys. Res. 74 (1969) 5507.

54 R.C. Harriss, Biological buffering of oceanic silica, Nature 212 (1966) 275.

55 R. Wollast, The silica problem, in: The Sea, 5, E.D. Goldberg, ed. (Wiley, New York, N.Y., 1974) 659.
56 L.H. Chan, J.M. Edmond, R.F. Stallard, W.S. Broecker, Y.C. Chung, R.F. Weiss and T.L. Ku, Radium and Barium at GEOSECS stations in the Atlantic and Pacific, Earth Planet. Sci. Lett. 32 (1976) 258.

57 I.N. McCave, Vertical flux of particles in the Ocean, Deep-Sea Res. 22 (1975) 491.

$58 \mathrm{H} . J$. Schrader, Fecal pellets: role in sedimentation of pelagic diatoms, Science 174 (1971) 55 .

59 K.K. Turekian and D.G. Johnson, The barium distribution in seawater, Geochim. Cosmochim. Acta 30 (1966) 1153.

60 C.E. Lambert, C. Jehanno, J.C. Brun-Cottan, N. Silverberg and R. Chesselet, Size distribution of suspended aluminosilicates in deep South Atlantic waters (submitted to Deep-Sea Res.).

61 P.E. Biscaye and S.L. Eittreim, Suspended particulate loads and transports in the nepheloid layer of the abyssal Atlantic Ocean, Mar. Geol. 23 (1977) 155.

62 J.K.B. Bishop, D.R. Ketten and J.M. Edmond, The chemistry, biology and vertical flux of particulate matter from the upper $400 \mathrm{~m}$ of the Cape Basin in the southeast Atlantic Ocean, Deep-Sea Res. 25 (1979) 1121. 